\title{
As siglas em cores no Trabalho das passagens, de W. Benjamin
}

\author{
Willi Bolle
}

$\mathrm{E}$

M SEU LIVRO de iniciação à métropole moderna, $R u a$ de mão única (Einbahnstraße, 1928), Walter Benjamin nos apresenta esta imagem de pensamento, intitulada Papelaria:

Place de la Concorde : o Obelisco. O que, há quatro mil anos atrás, foi ali gravado, ergue-se hoje no centro da maior das praças. Se isso the fosse profetizado - que triunfo para o Faraó! [...] Como se apresenta, na verdade, essa glória? Ninguém dentre dez mil que passam por aqui se detém; ninguém dentre dez mil que se detêm sabe ler a inscrição. [...] O Imortal está presente como o obelisco: rege um trânsito espiritual, que circula ruidosamente ao seu redor, e a inscrição ali gravada não é útil para ninguém (1).

Como é próprio da imagem de pensamento (Denkbild) enquanto gênero emblemático da vanguarda alemã dos anos 1920, o texto é constituído por uma legenda (scriptura) comentando uma imagem (pictura). De modo alegórico, a grande cidade contemporânea é considerada um texto difícil, criptografado, no limite da legibilidade. Pode-se dizer que Benjamin procurou decifrá-lo durante a vida inteira - desde o livro de estréia até seu projeto mais ambicioso, o das Passagens parisienses, ao qual mais tarde deu o título Paris, capital du século XIX e onde se propôs escrever uma história social dessa cidade (1927-1940) (2). No momento mais intenso do trabalho, que ficou inacabado, o autor inventou uma escrita secreta, não destinada à publicação: um sistema de 30 siglas em cores. A seu respeito existem até o momento duas teorias: por um lado, são vistas como signos de transferência, ou seja, como um recurso estritamente classificatório função essa totalmente evidente e que não pode ser negada. Por outro lado, esses pictogramas, pela sua qualidade estética, suscitaram a vontade de decifrálos, mas as dificuldades fizeram prevalecer a opinião de que antes se tratava de uma linguagem restrita e particular. Proponho aqui retomar o deciframento com uma teoria diferente. A meu ver, as siglas representam, no projeto de Benjamin, um procedimento mimético e mágico, destinado a ler o texto difícil da metrópole moderna; além disso, são elas poderosos recursos da arte mnemônica e da estruturação da obra. Trata-de de uma escrita-limite da historiografia, que pode ajudar a descobrir novas possibilidades nesse campo.

O uso de dispositivos icônicos na organização da obra não é uma característica exclusiva de Benjamin, mas uma prática bastante difundida entre os escritores 
do século XX. Como mostrou Louis Hay, num ensaio de 1989, a articulação entre escrita e desenho é de interesse especial para o estudo dos processos de criação estética (3). Os manuscritos são o lugar privilegiado para tais investigações, uma vez que os traços de inovação dos escritores, que são como as pulsações sismográficas de nossa época, permanecem freqüentemente insulados em esboços de uso particular, não destinados à publicação e por vezes enigmáticos, até mesmo indecifráveis. "Na escrita, nem tudo é verbo", lembra-nos Louis Hay. Além de sofrerem forte influência da civilização atual da imagem, os autores sentem-se também atraídos pelos tempos arcaicos em que nasceu a escrita a partir de garatujos e grafismos (4). É assim que, nos manuscritos modernos, observamos todo tipo de recursos semióticos: desde o rabisco lúdico por distração ou obsessão, até as representações de universos literários (Edgar Poe em Zettels Traum, de Arno Schmidt) e as modelizações de livros inteiros (Heinrich Böll, Gruppenbild mit Dame) - passando pela remodelagem corporal das letras (Kafka), as siglas como indícios de personagens e temas (Joyce, Finnegans Wake) ou as figuras geométricas e os desenhos (cadernos de Guimarães Rosa, Cahiers de Valéry) (5). Ora, a elucidação das redes de siglas nos autores do século XX “está longe de ser assunto encerrado e o estudo semiótico do manuscrito constitui, no essencial, um campo por explorar" (6).

\section{Documentos utilizados}

Esse panorama de oficinas literárias em escala universal e dos estudos semióticos em andamento nos ajuda a situar e a compreender melhor os meios gráficos utilizados por Benjamin. Anotemos, em primeiro lugar, as ocorrências de siglas na obra do autor e os documentos em que se encontram. Pelo que sabemos, Benjamin as utilizou apenas em seu Trabalbo das passagens, e mesmo nesse projeto, somente em 1938, quando elaborou um modelo, mostrando a "capital do século XIX" na forma de um estudo monadológico, da perspectiva de Baudelaire (7). Os documentos que contêm siglas, estas marcadas com lápis de cor, são de dois tipos. Por um lado, um amplo acervo de materiais, organizado em 36 maços temáticos (Konvolute), em que Benjamin reunira cerca de 3.500 fragmentos sobre a história social da cidade de Paris. Por outro lado, o plano de construção do livro-modelo (Charles Baudelaire, um poeta no auge do capitalis$m o$ ), estruturado por meio de 30 categorias teóricas e reunindo 1.745 fragmentos, daquele acervo, considerados os mais importantes. Os dois tipos de textos, acervo de materais e plano de construção, foram utilizados pelo autor um ao lado do outro, e são precisamente as siglas - siglas de transferência, como veremos abaixo - que evidenciam sua complementaridade e o fato de o livro sobre Baudelaire ser parte integrante do Trabalho das passagens (8). Por força das circunstâncias históricas, os dois tipos de textos foram separados e acabaram localizados em dois arquivos diferentes: o acervo de materiais e notas está no Theodor 
W. Adorno Archiv, em Frankfurt am Main, e o plano do livro sobre Baudelaire, na Bibliothèque Nationale de France, em Paris, onde foi reencontrado, juntamente com outros papéis, em 1981, por Giorgio Agamben (9). Tal dispersão e posterior redescoberta tiveram conseqüências profundas para a edição e recepção da obra e suscitaram interpretações bastante divergentes. Cabe lembrar, contudo, que a polêmica acerca do Trabalho das passagens existe desde a década de 1960 e remonta às controvérsias de Benjamin com Theodor W. Adorno e Max Horkheimer no tempo da gênese da obra (10).

A primeira informação sobre o uso de um sistema de siglas em cores na obra de Benjamin encontra-se na edição publicada em 1982 por Rolf Tiedemann com o título Das Passagen-Werk (11). A respeito dos manuscritos que serviram de base à impressão das 900 páginas de materiais e notas que constituem a parte principal do livro, o editor observava na época:

Na margem direita das anotações encontram-se retángulos, triângulos, círculos, cruzes deitadas e em pé, nas mais diversas cores, às vezes numa combinação de cores e tinta - ao todo 32 signos diferentes. À maioria dos maços temáticos, em que foram utilizados tais signos, estão anexas fichas estreitas, como se fossem marcadores de página. Nelas, Benjamin anotava em primeiro lugar até qual folha ele tinha revisto (durchgesehen) o maço em questão, depois - com um intervalo maior - a fórmula transferido (übertragen), $\mathrm{e}$ finalmente as siglas utilizadas nesse maço, embora nem sempre de forma completa (12).

Eis a primeira descrição das siglas e, tomada de Benjamin, a denominação que indica sua função: trata-se de signos de transferência (Übertragungs-Zeichen). As siglas marcam, portanto, determinados fragmentos do acervo de documentos, sendo que cada um deles é identificado por uma referência alfanumérica. Reproduzimos uma amostra na figura la (13). No fragmento escolhido, "J44,5", a letra indica o maço temático (" $\mathrm{J}=$ Baudelaire"), o primeiro número, a página, e o número depois da vírgula (dois sinais acrescentados pelo editor), o do fragmento na página do manuscrito.

Quanto às siglas de transferência anotadas na margem dos fragmentos - em nosso exemplo, um cruzamento (14) cor-de-laranja - é preciso levar em conta que Tiedemann, na época, dispunha apenas do texto a quo. Perguntava-se obviamente para onde haviam de ser transferidos. A sua hipótese segundo a qual poderia se tratar da elaboração de um manuscrito novo (15) revelou-se correta: o texto ad quem existe - sob forma de uma esquematização do livro-modelo sobre Baudelaire, ou seja, como plano de construção desse modelo (figura lb), escondido e posteriormente reencontrado na Bibliothèque Nationale.

Com esse achado se esclareceu a significação até então "misteriosa" do sistema das siglas. O próprio Benjamin fornece a chave, duplamente. Numa página, 
em posse de Agamben e reproduzida na edição italiana do Trabalho das passagens, encontra-se uma lista de $\mathbf{3 0}$ siglas com a devida decodificação:

< a margem é danificada e a sigla falta > Alegoria I

$\square \quad$ Antigüidade parisiense II

$\triangle \quad$ Eterno retorno III

Reação política III

$+\quad$ Jugendstil III

$[\ldots] \quad[\ldots]$

$\times \quad$ Spleen III

[e assim em diante] (16).

As mesmas siglas (17) acham-se distribuídas por 58 fólios brancos, de 22,5 $x 14,0 \mathrm{~cm}$, designando as 30 categorias construtivas (18), cujo conjunto constitui a parte principal do plano de construção do Modelo das passagens, na Bibliothèque Nationale. Assim como nas imagens de pensamento, cada sigla (pictura) é atribuída a uma categoria (scriptura) específica: o quadrado vermelho, por exemplo, corresponde à categoria Antigüidade parisiense, o triângulo azul, a Eterno retorno, o cruzamento cor-de-laranja a Spleen etc. (fig. 1b). Também fazem parte do plano de construção 16 fólios azuis com esboços de capítulos e uma dúzia de fólios, em papel cinza, amarelo, laranja e vermelho, com reflexões gerais sobre a composição; e ainda diversos fragmentos de redação e numerosas notas bibliográficas (19).

Ao comparar as figuras la e $\mathrm{lb}$, vemos como se realiza a função de transferência das siglas. No acervo de materiais e notas (texto a quo), elas marcam os fragmentos a serem utilizados no contexto de uma determinada categoria construtiva. Tomemos, por exemplo, a categoria "Spleen", cruzamento cor-de-laranja. Para essa folha, Benjamin transfere, um por um, e já com certa ordem construtiva, os fragmentos escolhidos no acervo. Se ele havia tomado, como primeiro fragmento, o "J44,5" do maço "J - Baudelaire", ele anota essa referência alfanumérica na folha "Spleen", juntamente com um resumo, geralmente de apenas uma linha. Nesse caso: "Proust: seccionamento do tempo". Depois, o fragmento seguinte ("J46a,10 livres de colère - Ira"), e assim em diante. Uma categoria construtiva pode reunir desde uma dezena até quase duas centenas de fragmentos. 
Função de transferência das siglas: a) TEXTO $A$ QUO

36 maços temáticos, cerca de $\mathbf{3 . 5 0 0}$ fragmentos, exemplo: maço "J" - Baudelaire

que je voudrais quelquefois ne plus dormir, si j'étais sûr de n'avoir pas trop de fatigue." Nadar: Charles Baudelaire intime Paris 1911 p 136/37 [<Baudelaire: CEuvres $>$ ed Le Dantec II p 696]

Proust vom "Balcon": "Bien des vers du Balcon de Baudelaire donnent aussi cette impression de mystère." (p 644) Dies im Gegensatz zu Hugo: "Victor Hugo fait toujours merveilleusement ce qu'il faut faire... Mais la fabrication - la fabrication même de 1 ' impalpable - est visible." Marcel Proust: A propos de Baudelaire NRF XVI Paris 1921 <p 643/644>

$\mathrm{Zu}$ den Rahmengedichten: "Le monde de Baudelaire est un étrange sectionnement du temps où seuls de rares jours notables apparaissent; ce qui explique les fréquentes expressions telles que 'Si quelque soir' etc." $M$ Proust: A propos $\mathrm{d}<\mathrm{e}>\mathrm{B}<$ audelaire $>$ NRF XVI ljuin 1921 p 652

Figura la: Acervo de materiais e notas do Trabalho das passagens Theodor W.Adorno Archiv, Frankfurt am Main

Função de transferência das siglas: b) TEXTO $A D$ QUEM 30 categorias construtivas, 1.745 fragmentos, exemplo: categoria "Spleen"

\section{Spleen $X$}

J44,5 Proust: sectionnement du temps J46a, 10 livres de colère - Jähzorn J48a,5 umbra vitac: Stillsetzung der Natur J47a,2 nichts Neues mehr auf der Welt (Fusées XxII)

(Ewige Wiederkunft)

S8a,4 spleen Miniaturmodell des Weltgeists der ewigen Wiederkehr (Ewige Wiederkehr)

O2a, 5 sectionnement du temps im jeu

O4a, I France über das Spiel

J49,5 sectionnement der Sekunden (Chambre double)

J50,2 Wille den Weltlauf zu unterbrechen J50a,1 Jähzorn als sectionnement du temps I2,6 Nihilismus Kern der Gemütlichkeit; Wille B's sie zu stören

Noa, 2 intermittierenter Charakter ter Tradition bei Hugo

N9,4 Kontinuität als Katastrophe der Ḧberlieferung N9a,1 die Katastrophe: daß es so weiter geht

Figura lb: Plano do Modelo das passagens Bibliothèque Nationale de France 
A função de transferência a as siglas está, portanto, perfeitamente elucidada, na opinião de todos os especialistas. Tal utilização estritamente classificatória, à qual se limitou Tiedemann, é realçada também pelo fato de ele ter podido substituir as siglas em cores por de-ignações alfabéticas ("quadrado vermelho: $\mathrm{k}$ ", "triângulo azul: h", cruzamento amarelo [recte: cor-de-laranja]: c", etc. - sem comprometer sua função organizadora (20).

\section{Além da razão classificatória}

Existe, porém, uma outra dimensão das siglas, que é de ordem estética. Longe de serem arbitrárias e substituíveis, as siglas, muito pelo contrário, podem ser uma linguagem mimética ou fisiognômica com valores próprios, trazendo novas informações, semânticas e estruturais, para a compreensão do plano de construção do Modelo das passagens. Sabemos, por exemplo, que a vertical roxa que divide um retângulo preto representa, no sistema de Benjamin, a Melancolia, o grande ponto de cor preta, o Tédio e o cruzamento cor-de-laranja, o Spleenmas o que não sabemos é por que o autor escolheu precisamente tais formas e tais cores para traduzir os três conceitos em questão.

Uma análise pioneira dos manuscritos parisienses de Benjamin e que redimensionou nosso conhecimento do Trabalbo das passagens foi realizada entre 1983 e 1990 por Michel Espagne e Michael Werner (21). No que concerne às siglas, os dois pesquisadores não se limitaram a ver nelas apenas a função organizadora. Considerando o sistema das siglas em cores "a parte mais espetacular" desses escritos (22), adiantaram observações interpretativas sobre o significado de diversas formas, cores e relações. Num determinado momento, porém, interromperam sua pesquisa, com esta constatação:

O caráter pluridimensional do sistema benjaminiano de signos não deixa de lembrar certas tradições cabalísticas. [...] Mas cabe salientar que sua dimensão, a qual sem dúvida é lúdica, o confina num domínio pertencente à ordem do secreto ou, em todo caso, do particular. Nada disso haverá de filtrar na esfera da comunicação intersubjetiva - não há nem mesmo um solilóquio explícito a seu respeito. É como se nos defrontássemos com uma rede subterrânea de afinidades e oposições que, embora sustentando a construção intelectual elaborada por Benjamin, erguia-lhe também fronteiras invisíveis (23).

Considerando-se o ponto a que chegaram os dois colegas, valeria a pena, a meu ver, retomar a caminhada com fồlego novo. Em suas ponderações, na verdade, há tão-somente uma restrição realmente desalentadora: a hipótese de uma linguagem privada, de um sistema absolutamente fechado, restrito a uma única pessoa. Para todas as outras observações (linguagem secreta, subterrânea, cabalistica etc.), tais obstáculos não me parecem intransponíveis, e é precisamente nas "confusas palavras", que, por vezes, escapam dessa floresta de signos urbanos que se pode descobrir o código. 
Eis o momento de projetar o que será o pano de fundo de nossas incursões pela Paris de Benjamin: um quadro sinóptico mostrando todas as categorias construtivas e suas siglas no Modelo das passagens (figura 2). No eixo horizontal encontram-se dispostas as cores segundo a ordem do arco-íris: vermelho, laranja, amarelo, verde, azul e roxo; à direita, acrescentamos as cores que são para Benjamin as da morte: o marrom e o preto; à esquerda, o cor-de-rosa (a cor da aurora). No eixo vertical estão registradas as formas, numa progressão que vai do elementar ao mais complexo. Com base no estudo de Kandinsky, Ponto, linha, plano (24), distinguimos o ponto, as linhas (retas em forma de cruzamento ou cruz, linha ondulada ou serpentiforme) e os planos (quadrados, triângulos, círculos, secção de círculo), aparentes (vazios) ou reais (cheios); por último vêm as siglas complexas, formadas por montagem de vários elementos: vertical dividindo um retângulo, cruz numa elipse, círculo num quadrado cheio etc. (25).

Minha hipótese é que a escrita benjaminiana das siglas, embora secreta e esotérica, passa, assim mesmo, para a esfera da comunicação social. Quer dizer: na base da escolha das formas e cợres haveria, para além das razões subjetivas e particulares, referências intersubjetivas que estariam traduzindo imagens e conceitos coletivos (26). (Ao exemplo dos sonhos, os quais também são projetados em primeiro lugar sobre uma tela particular, mas que - pelo que nos mostra Benjamin enquanto "historiador interpretando sonhos coletivos" - em determinado momento transcendem o particular para se tornar parte do imaginário social).

Proponho, portanto, uma interpretação da forma e da cor das siglas, como se elas fossem a tradução ou o proto-texto pictográfico das categoriais conceituais. Em outras palavras: trata-se de um estudo do plano de construção do Modelo das passagens a partir de um código mais arcaico que a escrita verbal. $O$ interesse teórico desta pesquisa diz respeito tanto a questões semióticas da crítica genética quanto a questões de método da historiografia, em especial daquela que focaliza o espaço urbano. Como método de escrever a História e como ambição teórica, Benjamin havia-se proposto o seguinte objetivo:

Registrar a história do Trabalho das passagens em seu desenvolvimento. Seu elemento propriamente problemático: não renunciar a nada, mostrar a superioridade da apresentação materialista da História sobre a tradicional, através do seu caráter figurativo (27).

Acompanhemos Benjamin nessa tentativa. Com o termo figurativo ele não se refere a imagens ilustrativas, e sim, a imagens dialéticas, que são os elementos constitutivos de sua escrita da História. Serão elas o objeto de nossa exposição, a partir da perspectiva das siglas que funcionam como abreviaturas dessas imagens. Metodologicamente falando, trata-se de um caso-limite da historiografia, que destaca o suporte materialista do discurso do historiador: a escrita. 
grande ponto

cruzamento

cruz

linha

serpentiforme

quadrado

quadrado cheio

triângulo

triângulo invertido

triângulo che1o

círculo

secção de círculo

vertical dividindo

um retângulo*

cruzamento* um retângulo

cruzamento* num quadrado

cruz*

numa elipse

cruz*

num círculo

cruz* cortando

um círculo cheio

cruz*superposta

a um círculo cheio

círculo num

quadrado cheio

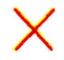

Spleen

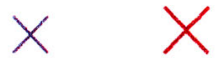

Dandy Prostituta Mercado literário
Antigüidade parisiense

Novidade

Reação Lesbos

política

Dante / Fisionomia do Inferno

o Herói

$\triangle$ Rebelde e alcagüete

Eterno retorno

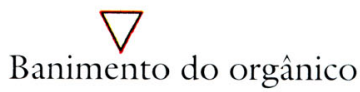

Gautier/a arte pela arte

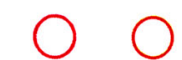

Recepção Recepção

em geral

Tradição 
Eis a formulação do problema. E quanto ao caminho da solução? De acordo com o assunto, optei pela forma de um ensaio imagético. O leitor é convidado para um percurso pela Paris de Benjamin, em que propomos esboçar um deciframento de todas as $\mathbf{3 0}$ siglas (era preciso não renunciar a nada). Para evitar explicações fastidiosas, as siglas foram reunidas em sete constelações, facilmente memoráveis, cada uma delas acompanhada de uma tese-resumo. Os elementos teóricos necessários ao deciframento dessa escrita esotérica serão fornecidos ao longo do percurso. Evidentemente, podem ser encontrados, quase por toda a parte na paisagem urbana, círculos vermelhos, triângulos azuis e cruzes amarelas - mas não tenho em mente, de forma alguma, a fabricação de um Frankenstein semiótico. A chave para a decodificação das siglas benjaminianas, nós a encontraremos, sobretudo, no plano de construção, que levei vários meses a decifrar, e nos 1.745 fragmentos aos quais os resumos se referem; nas contribuições de certos artistas e críticos construtivistas, contemporâneos de Benjamin ou pertencentes à essa tradição; e ainda nos sistemas mais antigos da escrita. Há ainda uma outra chave, muito especial, encontrada num manuscrito recém-descoberto...

\section{Oficina de historiografia}

\section{Siglas: 1. Melancolia 2. Tédio 3. Spleen}

TESE-RESUMO: A historiografia de Benjamin inspira-se na idéia da ciência como arte (Goethe) e se quer essencialmente figurativa, como se pê pela utilização de imagens dialéticas e de um sistema de siglas em cores. Foi com artistas-criticos, Dürer e Baudelaire, que Benjamin aprendeu a aperfeiçoar seu método, e é na obra deles que se pode descobrir uma parte do seu repertório de formase cores. Todavia, a sigla, que é a abreviatura imagética (pictura) de uma categoria teórica (scriptura), não pertence ao gênero ilustrativo; tratase antes de "imprimir a imagem na memória, do que enfeitá-la e pintá-la".

O conceito de oficina de historiografia é formado por analogia aos termos chantier d'écriture, familiar aos críticos geneticistas, e atelier d'bistoire, introduzido por François Furet (28). Ilustramos esse conceito pela presente constelação I, a tríade da Melancolia. Se a melancolia, o tédio e o spleen são estados emotivos suscetíveis de se tornarem patológicos, por outro lado, segundo as explicações de Aristóteles e de Marcilius Ficinus, trata-se de disposições de espírito favoráveis para registrar a imagem sensorial e intelectual de uma época, como o observamos nos autores aqui em questão.

1. A sigla Melancolia (vertical roxa dividindo um retângulo preto) pode ser considerada como a abreviatura de uma imagem, precisamente da gravura Melencolia I (1514) de Albrecht Dürer (figura 3). Nesse enquadramento sombrio, temos, em forma de representação alegórica, a reflexão do artista sobre o seu trabalho. Reflexão como interrupção. 
Figura 3: Albrecht Dürer - Melencolia I (1514)

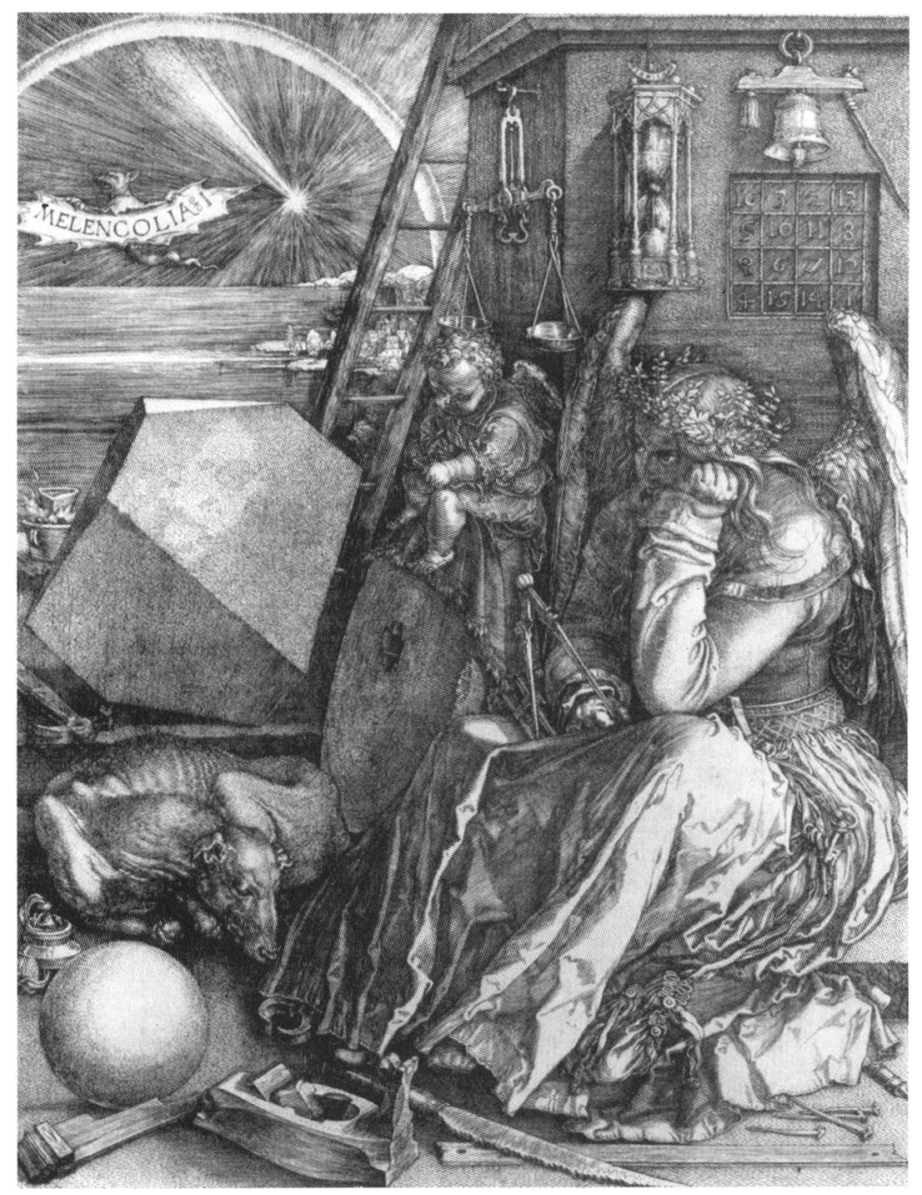

Esta é figurada na sigla pelo traço roxo que corta e, na gravura, pela incidência dos raios do astro, assim como pela aparição do arco-íris. A cor roxa, segundo Paul Klee, marca o ponto em que o círculo das cores, calcado sobre o modelo do arco-íris, é partido (29). O artista interrompe seu trabalho e medita, como se dialogasse com outra esfera, transcendental. Em seu livro sobre o drama barroco alemão, Benjamin oferece uma visão do gênero e da época através de sua interpretação dessa gravura (30). Trata-se de uma alegoria da própria idéia de construção, de uma imagem da condição do artista nos tempos modernos que surgem no horizonte. Na folha de Dürer, pode-se descobrir todo um repertório de formas que Benjamin utilizou em suas siglas: pontos como os que representam o olhar da Melancolia ou o traçado do instrumento que ela segura nas mãos e que pode servir ao mesmo tempo para escrever, desenhar e medir: servir, em suma, à criação; linhas como as da perspectiva ou as que se cruzam na ampulheta como representação do tempo, ou ainda as linhas onduladas configurando o corpo do cão que dorme e sonha ou do demônio nefasto flutuando na atmosfera; planos como o círculo que representa a esfera, emblema da concentração; o quadrado mágico e o enquadramento da cidade no fundo; ou enfim, no centro, o enigmático emblema da pedra, com sua combinação de triângulos. 
2. O tédio (grande ponto preto) é a forma urbana da melancolia, resultado da monotonia provocada pela haussmannização, tal como Benjamin a estudou no Trabalho das passagens. Neste caso também, podemos considerar a sigla como abreviatura de uma imagem: Baudelaire trabalhando, em pintura de Courbet (figura 4). (É claro que tais correspondências, aqui estabelecidas, entre siglas e imagens são um arranjo interpretativo do qual assumo a responsabilidade - ele se justifica, porém, por estar baseado em elementos teóricos e estéticos propostos por Benjamin; evidentemente, há outras interpretações possíveis). $\mathrm{O}$ mesmo signo que acabamos de ver na gravura de Dürer - a esfera enquanto emblema da concentração - reaparece na figuração do Tédio: um grande ponto preto. Ao tédio que, em forma de Angústia, finca sua bandeira preta no crânio do poeta ( $\mathrm{cf}$. o poema LXXVIII das Flores do mal, intitulado "Spleen"), este

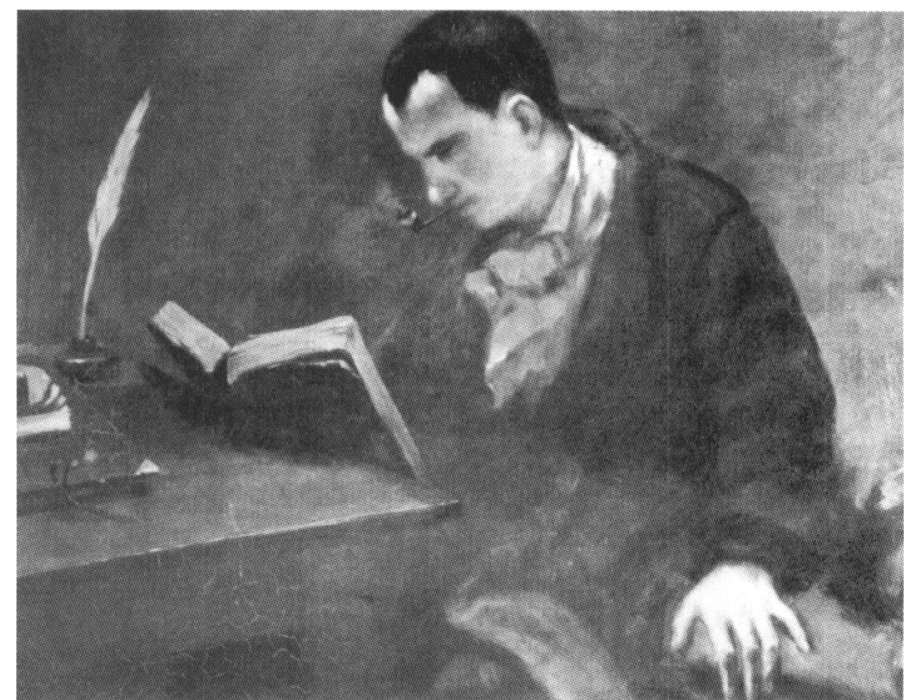

Figura 4: Baudelaire, em pintura de Courbet responde com a construção de sua obra. Baudelaire é representado como um autor antigo. Em contraposição ao ateliê alquimicamente abarrotado da Melancolia de Dürer, o do poeta da Modernidade apresenta-se admiravelmente despojado: um livro, uma pena e o escritor concentrado em seu trabalho. $O$ resultado será um livro de poemas que - segundo Claude Pichois e Jean Ziegler - ocupa apenas um centímetro nas prateleiras, mas revolucionou a poesia moderna (31). Seguindo o exemplo das siglas benjaminianas, onde a pictura é completada por uma scriptura, proponho para o quadro de Courbet esta legenda:

Vocês se lembram de um tableau (sim, trata-se de um autêntico tableau!) escrito pela pena mais poderosa da nossa época e cujo título é $O$ homem das multidões? Atrás da janela de um $c a f e ́$, um convalescente, contemplando a multidão com prazer, se envolve pelo pensamento com todos os pensamentos que se agitam ao seu redor. [...] Suponham um artista que estivesse sempre, espiritualmente, no estado de convalescência, e terão a chave do caráter de M.G.(32).

Nessa passagem, extraída do ensaio $O$ pintor da vida moderna, Baudelaire nos fala de Edgar Poe e de Constantin Guys, mas, sobretudo, do seu próprio método. Destacam-se o elemento figurativo-alegórico, uma escala cromática muito elaborada e a arte mnemônica. Baudelaire está "mais interessado em imprimir 
a imagem na memória, do que em enfeitá-la ou pintá-la"(33). Dentro dessa concepção, o artista desempenha o papel de historiador, uma vez que, por meio de seus desenhos e quadros, cria "arquivos preciosos da vida civilizada" moderna (OC, p. 1191s.). O mesmo objetivo se propôs, com os meios do pesquisador, Walter Benjamin, aspirando a criar um método e um discurso de historiador em que "a ciência seria pensada necessariamente como arte" (so müssen wir uns die Wissenschaft notwendig als Kunst denken) - eis o que diz na primeira frase de seu livro sobre o drama barroco, com as palavras de Goethe, extraídas de Materiais para a história da teoria das cores.

X 3. Spleen, cruzamento cor-de-laranja - sigla mais dificil de decifrar que as duas anteriores, em que era evidente o uso da cor preta para expressar estados melancólicos. Observemos uma terceira imagem, da qual esta sigla é uma possível abreviatura (figura 5): um homem trabalhando numa sala de arquivos, copiando informações para organizar novos arquivos, os quais, por sua vez, haverão de ser guardados em outros arquivos... É Walter Benjamin na Bibliothèque Nationale, trabalhando no seu projeto das Passagens, numa fotografia tirada por Gisèle Freund. Como legenda, escolhemos esta observação de Bertolt Brecht em seu Diário de trabalho, de 25 de julho de 1938 :

benjamin está aqui. escrevendo um ensaio sobre baudelaire. [...] estranhamente é um spleen que possibilita que benjamin o escreva. ele parte de algo que chama de anirk [...] e que estaria se desintegrando, ultimamente [...]. a aura se desintegra em virtude da reprodutibilidade das obras de arte. tudo isso é misticismo, sendo que ele recusa o misticismo. nesta forma adapta-se a concepção materialista da história! é horrível (34).

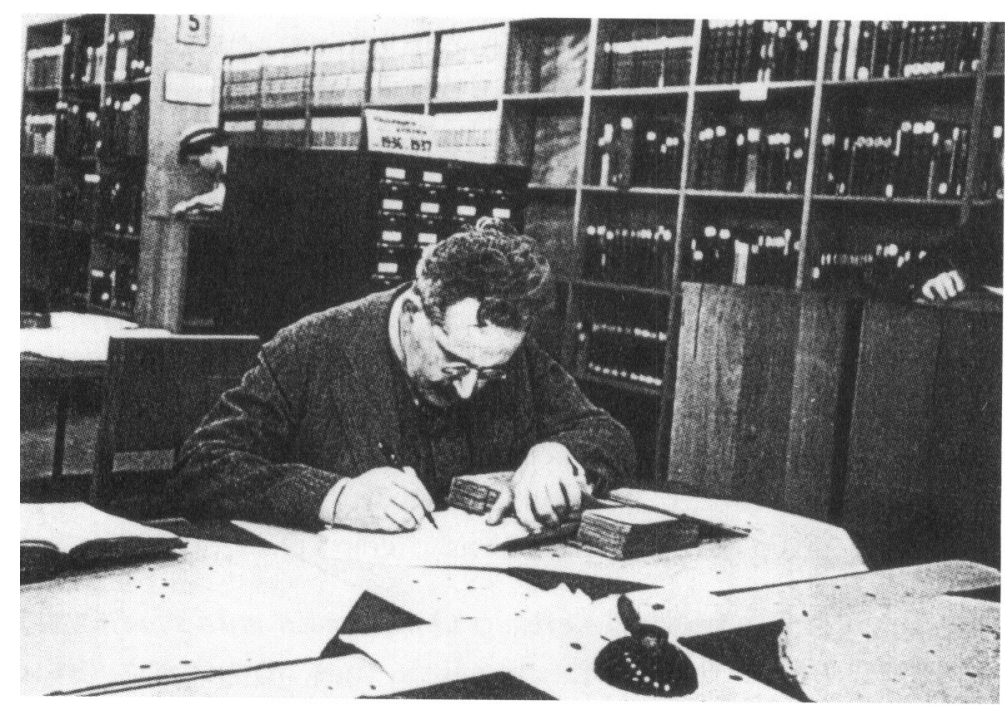

Figura 5: Walter Benjamin em 1937 na Bibliothèque Nationale, em fotografia de Gisèle Freund 
Nosso trabalho consistirá precisamente em explicar esse método horrível de escrever a história e de verificar se se trata mesmo de misticismo. Em 1937, Benjamin recebera de Horkheimer a incumbência de escrever para a Zeitschrift für Sozialforschung, em Nova Iorque, um artigo materialista sobre Baudelaire (35). Era a primeira oportunidade, para ele, de vir a público com o projeto no qual trabalhara já durante uns dez anos e para o qual havia acumulado um enorme acervo de materiais e notas. Pôs-se então a reler a totalidade desses fragmentos e a escolher 1.745 deles para organizá-los em forma de um plano de construção bem detalhado. A idéia de escrever um simples artigo acabou sendo substituída pelo projeto de um livro, que seria um modelo do Trabalho das passagens (36). Seu ponto de fuga e subtexto seriam constituídos pelas experiências históricas vividas por Benjamin e sua geração entre 1923 e 1938. A ameaça da Segunda Guerra Mundial criou um clima de urgência para ele realizar esse trabalho. $\mathrm{O}$ livro, que se chamaria Baudelaive, um poeta no auge do capitalismo, seria composto de três partes: "Baudelaire, poeta alegórico", "A Paris do Segundo Império na obra de Baudelaire" e "A mercadoria como objeto poético". Em comparação com o exposé de 1935 (37) e com o acervo de documentação, houve dois avanços qualitativos: $1^{\circ}$ A descoberta de uma perspectiva - a capital do século XIX era apresentada pelo prisma do poeta da modernidade - e, com isso, a opção por uma historiografia monadológica, inaugurada com o livro sobre o drama barroco; e $2^{\circ}$ A substituição de categorias de coleção e inventário por categorias construtivas, visando uma interpretação filosófica e histórica do fenômeno da metrópole moderna. Em vez de um artigo, Benjamin enviou a Horkheimer e Adorno, em outubro de 1938, uma das três partes do livro - a do meio. A recusa da publicação teve como conseqüência a interrupção do projeto, que ficou portanto inacabado. (Enquanto a parte II teve sua redação concluída, as partes I e III só se configuraram como uma coletânea de fragmentos soltos, intitulada Parque central (38); trata-se de uma forma intermediária entre reflexões gerais e uma pré-redação). Resta-nos apenas imaginar o que teria sido o modelo integral do Trabalho das passagens, com base no plano de construção, que representa "a sua estruturação mais avançada" (39).

Algumas características gerais do projeto estão presentes de forma extremamente concentrada na sigla Spleen: o cor-de-laranja (orange) é utilizado unicamente ali, portanto, como uma cor rara e preciosa, vizinha da cor-de-ouro, como se resumisse a magia de um sistema hieroglifico; o cruzamento representa a dialética entre a dispersão (a multidão de informações acumuladas) e a concentração (o espaço labiríntico da Metrópole apreendido a partir de um foco central); as duas linhas cor-de-laranja que se cruzam configuram um seccionamento do tempo, o desenho de uma ampulheta pela qual o tempo escoa, mas também o ponto em que o homem que se concentra pode captar o momento favorável. 


\section{Uma escrita fisiognômica}

\section{Siglas: 4. Elementos fisionômicos 5. o Dandy 6. o Herói}

TESE-RESUMO: Considerando, na tradição de Edgar Poe, a metrópole moderna como um texto no limite da legibilidade, Benjamin, diante do desafio de decifrar a escrita da cidade, recorreu a um procedimento mimético: inventou um sistema criptográfico de 30 siglas em cores, correspondendo a um número igual de categorias construtivas por meio das quais estrutura sua história social da cidade de Paris no século XIX. Ao retomarem o mesmo número de letras - 30 - do primeiro alfabeto da humanidade, as siglas benjaminianas situam-se num limiar da escrita: $u m$ dos lados é voltado para a evolução alfabética moderna (arbitrariedade do signo), o outro, para as formas mais antigas, ideográficas e pictográficas (caráter fisiognômico e mágico do signo).

No seu ensaio Teoria das semelhanças (2 $2^{\text {a }}$ versão: Sobre a capacidade mimética, ambos de 1933) (40), Benjamin fala de um poder mimético que se manifesta na atividade de cada escrevente e que foi da maior importância nos tempos em que nasceu a escrita. Esse seu lado mágico - intimamente ligado à physis, natureza e corpo, e à fisionomia - coexiste com seu lado convencional, semiótico ou comunicativo. Embora a capacidade mimética tenha-se enfraquecido no decorrer da história da humanidade, existe ainda hoje um acesso a ela e a todo um saber oculto dos antigos, pela via da escrita, esse arquivo de similaridades não-sensoriais (Archiv unsinnlicher Äbnlichkeiten). Temos aí um conceito eqüidistante - com bem o explicou Winfried Menninghaus (1980) - do mimetismo da linguagem e da arbitrariedade do signo (41), que nos possibilita compreender as imagens gráficas (Schriftbilder) de Benjamin como uma escritalimite.

É no limiar entre as escritas alfabéticas e as tradições pictográficas que se situa o sistema de siglas de Benjamin, criado, pelo que sabemos, de uma só vez, e composto de 30 signos, número igual ao das letras do primeiro alfabeto da humanidade, inventado em Ugarit (Síria-Palestina) por volta de 1500 antes de nossa era (42). Todavia, o conceito das similaridades não-sensoriais é ainda mais antigo, devendo ser procurado entre os egípcios. Se os inventores do alfabeto optaram a favor da arbitrariedade e contra a mímesis, é preciso lembrar, com Jean-François Champollion, que os antigos egípcios utilizaram "simultaneamente signos de idéias e signos de sons", isto é, ideogramas ao lado de símbolos fonéticos (43). Em outras palavras: foram os egípcios os primeiros a terem a idéia do alfabeto, mas, em vez de aderir a ela, preferiam permanecer fiéis ao sistema mais antigo dos hieróglifos, igualmente apropriado para a transcrição fonética, racional e analítica, quanto para a representação ideográfica, analógica e sintética. Portanto, uma escrita de livre trânsito, de limiar, passagem e metamorfose - em suma: uma escrita mágica. 
Com todo respeito pelas diferenças entre hieróglifos e siglas modernas, nós, leitores de Benjamin, dispomos também, desde a recente publicação de um manuscrito singular, de uma espécie de pedra de Roseta. No volume de adenda (Nachtrüge) aos Gesammelte Schriften apareceu em 1989 este pequeno texto, que pertence aos esboços da "Crônica berlinense" (Berliner Chronik, 1932):

Quando eu estiver velho, gostaria de ter no corredor da minha casa

Um mapa Pharus de Berlim

Com uma legenda

Pontos azuis designariam as ruas onde morei

Pontos amarelos, os lugares onde moravam minhas namoradas

Triângulos marrons, os túmulos

Nos cemitérios de Berlim onde jazem os que foram próximos a mim

E linhas pretas redesenhariam os caminhos

No Zoológico ou no Tiergarten

Que percorri conversando com as garotas

E flechas de todas as cores apontariam os lugares nos arredores

Onde deliberava sobre as semanas berlinenses

E muitos quadrados vermelhos marcariam os aposentos

Do amor da mais baixa espécic ou do amor mais abrigado do vento.

(GS II, p. 714)

A existência de afinidades entre a topografia da grande cidade e as estruturas mentais de seus habitantes era uma concepção cara a Benjamin: "Desde há muitos anos, estou brincando com a idéia de organizar o espaço da vida (bios) graficamente, na forma de um mapa. Primeiro, pensei num mapa Pharus [...]" (44). Aqui está ele imaginando um mapa da cidade equivalente à cartografia de sua vida afetiva. Esse mapa mnemônico de Berlim era estritamente pessoal, não destinado à publicação. Do ponto de vista formal, assemelha-se a um esboço de soneto, na tradição dos tableaux urbanos. Mas, sobretudo, esse Pharusplan de 1932 é um texto fundador, na medida em que instaura um código duplo, simultaneamente pictográfico e literário. Com isso, fornece uma chave privilegiada para o deciframento do outro mapa de cidade, constituído pelas siglas do Modelo das passagens, das quais é o modelo rudimentar e o único proto-texto.

Transponhamos a legenda do mapa mnemônico de Berlim para a planta das Passagens parisienses. É com base no primeiro que formamos nossa constelafão II, composta de três siglas de cor azul. Em sua obra sobre a história cultural das cores, John Gage (1994) lembra que, no registro das cores mentais do início do século XX, tiveram um papel de destaque os pintores do círculo Der Blaue Reiter. Franz Marc, coeditor (juntamente com Kandinsky) do almanaque do grupo, escreve em 1910: "O azul é o princípio masculino, seco e espiritual" (45). Esse princípio, simbolizado pelo azul, aparece em todas as siglas da nossa constelação. 
4. Elementos fisionômicos, cruz preta sobreposta a um grande ponto (ou pequeno círculo) azul. A sigla retoma a legenda inicial do Pharusplan de Berlim, onde designava o eu do autor e sua localização: "Pontos azuis... as ruas onde morei". O ponto azul, enquanto traço inaugural, institui um eu que se funde com a escrita. Sua fisionomia aparece riscada por uma cruz preta. Num autoapagamento lúdico, o historiógrafo se retira para o segundo plano, deixando o lugar para um alter ego: Baudelaire, o poeta da modernidade - o qual, por sua vez, desaparece nos papéis que representa: o dandy e o herói.

5. o Dandy, cruzamento azul. O dandy, caráter social criado pelos ingleses, destacando-se pela capacidade de reagir com perfeito domínio de si diante dos altos e baixos do comércio mundial, exprimia o desejo de preservar as qualidades aristocráticas da elegância, do requinte e da distinção, opostas à trivialidade burguesa. O dandismo era, para Baudelaire, "o último brilho de heroísmo em tempos de decadência" (46).

6. o Herói, quadrado azul. Além do protagonista, a sigla designa também, por metonímia, o seu espaço de atuação. O plano aparente azul é o palco, onde o poeta e o crítico, seu duplo, representam o drama da modernidade, tendo como parceira e antagonista a cidade (ver nossa constelação IV, Planos de Paris). Tendo identificado a modernidade como "uma atmosfera e um campo hostís" ao trabalho criador [J39a,1], o escritor se propõe uma tarefa heróica:

dar uma forma à Modernidade [...] definir a fisionomia da Modernidade (GS I, p. 584 e 581 ; OE III, p. 80 e 77).

- o que é sugerido também pela própria forma da sigla, assim como por todas as demais que representam o espaço da cidade: trata-se de um fac-simile de topografia de página.

\section{Representação do tempo}

\section{Siglas: 7. Jugendstil 8. Reação política 9. Paris ctônica 10. Recep̧̧ão 11. Recep̧̧ãa em geral 12. Tradição}

TeSE-Resumo: Para expressar as diferentes relaçoes de tempo - história anterior, história posterior, simultaneidade, superposicão, telescopagem, seccionamento - o discurso bistoriográfico recorre freqüentemente a metáforas visuais, espaciais, artisticas ou técnicas. As siglas iconográficas expressam tais relações de modo mais eloqüente que o mero registro verbal. Elas traduzem a concepção de história proposta por Benjamin como alternativa ao historicismo: uma constelação de imagens históricas autênticas, que estilhaçam o continuum do tempo "linear", "bomogêêneo"e "vazio" (47).

Nossa terceira constelação ilustra a representação do tempo e é formada 
por dois sub-grupos: as três siglas de cor amarela (7-9) e uma tríade de siglas vermelha e cor-de-rosa (10-12).

+ 7. Jugendstil, círculo amarelo cheio, cortado por uma cruz preta. Tentemos compreender porque Benjamin representa a época do Jugendstil dessa forma.O amarelo retoma uma legenda do mapa mnemônico de Berlim: "Pontos amarelos, os lugares onde moravam minhas namoradas". Trata-se das moças em flor que Benjamin conheceu no seu tempo de estudante. Sobre a significação do amarelo nos diz Franz Marc:

O amarelo representa o princípio feminino, doce, alegre e sensual.[...] as cores se amam [...] azul o céu e amarelo o sol [...] (48).

Reencontramos esse elemento alegre e sensual no art nouveau: a casa própria concebida como um cálice de flores (Van de Velde), a ornamentação floral das entradas do metrô parisiense. Benjamin interpreta esse estilo como uma fuga diante do mundo industrializado moderno. No Jugendstil a burguesia se refugiava num sonho, "quinze anos antes de ser despertada pelo retumbar" da guerra tecnológica moderna $[S 4,1 ; S 4 a, 1]$.

O Jugendstil é a história posterior (Nachgeschichte) da obra de Baudelaire, na medida em que as Flores do mal anteciparam de modo visionário e crítico o tema floral do modern style (cf. GS VII, p. 751 e 763). Por outro lado, o Jugendstil é a história anterior (Vorgeschichte) da obra de Benjamin, por ter impregnado a Jugendbewegung $[S 5,3]$, o movimento de juventude formador da personalidade do jovem crítico. Um de seus mestres foi Stefan George, que oferecia aos jovens um refúgio em versos mágicos, uma poesia-sortilégio que sensibilizava:

assim como o vento toca as "flores da pátria primeva", as quais, lá fora, convidavam sorrindo ao longo sono (49).

Compreendemos agora o que está emblematizado pela sigla Jugendstil. A cruz preta cortando a plenitude do amarelo em flor é o tópos da bela morte. Representação de um sonho coletivo.

Mas também o despertar desse sonho. No momento em que Benjamin estava na fila diante de um quartel para alistar-se como voluntário, nos primeiros dias de agosto de 1914, a notícia de que seu melhor amigo, o poeta Fritz Heinle, de 19 anos, e a namorada se suicidaram, levou-o a compreender subitamente que ele e seus colegas eram usados, em nome de uma mitologia, para ir aos campos de batalha e lá morrer. A partir daí, a cruz da morte se sobrepôs, em sua memória, à imagem das flores. Porta-voz de "uma geração que fizera entre 1914 e 1918 uma das mais monstruosas experiências da história mundial", Benjamin começou a reler de maneira crítica o Jugendstil. 
8. Reaf̧ão política, cruz arnarela. Esta é, por assim dizer, recortada do círculo cheio amarelo de 7. Jugendstil, deixando como marca a cruz preta da morte. Com a categoria Reação(-ões) política(s), Benjamin se refere ao golpe de Estado de Luis Bonaparte, em 1851, mas também à ditadura nazista. As frases do passado retornam: apologia da violência, como em De Maistre - "a guerra é divina" [J65a,1] -, e culte de la blague, como nesta afirmação de Baudelaire:

Bela conspiração para organizar o extermínio da raça judia. (Mon cæur mis a $n u$, em $[J 40,1])$.

Benjamin cita essa frase em 1938, ano em que começaram em toda a Alemanha as perseguições em massa contra os judeus. Pouco depois, estes foram obrigados a usar a estrela de Davi (estrela amarela). O emprego pejorativo e discriminatório do amarelo já foi mencionado por Goethe:

Quando [...] é puxada para o lado negativo [...], a cor da honra e do deleite se deteriora na cor da vergonha, do desagrado e do asco. É o que pode ter dado origem aos chapéus amarelos dos banqueiros fraudulentos e aos anéis amarelos nas capas do judeus (50).

9. Paris ctônica, círculo preto num quadrado amarelo cheio. Por que foi escolhido o amarelo, simbolizando o sol, o calor e a alegria, para representar o mundo subterrâneo, e não a cor cinza - cinereum em latim, bigia e cenericcia êm italiano -, conforme a tradição humanista? (51) Estamos diante da mais complexa das siglas benjaminianas, a única em que um plano se sobrepõe a outro. Este encavalamento de planos diferentes (círculo, quadrado), embora mantendo a mesma cor, é um recurso gráfico para traduzir a relação entre tempos distintos:

Para o historiador materialista, a época de que ele trata, é apenas a história anterior daquela que lhe concerne $[\mathrm{N} 9 \mathrm{a}, 8]$.

Graficamente, temos em primeiro plano a experiência do historiador, ligada à época do Jugendstil, materializada pelo círculo - que é recortado sobre o quadrado, em segundo plano, emblematizando o tempo anterior da Paris ctônica. Através desse meio visual, Benjamin traduz a relação entre história anterior e posterior (estando a segunda contida na primeira) e um procedimento fundamental da historiografia: a arte de construir uma perspectiva.

Tratava-se para o historiador de compreender a mitologia de sua própria época à luz da "Urgeschichte do século XIX" [N3a,2] (52). Pode-se imaginar esse trabalho da memória como uma descida num poço do tempo. Descida à morada dos mortos, conforme o modelo de Virgílio e de Dante, para recuperar o que se tinha perdido. Não seria "a imagem da felicidade", tal como evocada por Benjamin nas teses Sobre o conceito de história? As vias de acesso à Paris ctônica são múltiplas. Desde o uso diário das entradas do metrô pelos habitantes da grande 
cidade [Cla,2], em que Benjamin sabia detectar os resíduos de rituais e mitologias antigas, até os pesadelos baudelairianos de labirintos repletos de uma "multidão de miolos, de carne humana e de ossos triturados" [ J44,3].

De todas as descidas à cidade ctônica, às camadas de calcário mais profundas que a rede do metrô, onde à rocha friável se mistura o pó dos mortos, nenhuma é tão memorável como a de Nadar:

As fotografias de Nadar nas catacumbas [Y2,2].

O fotógrafo das catacumbas de Paris é o Virgílio do mundo moderno. Fotografar nas catacumbas é, literalmente, escrever com luz no reino das trevas. Não seria isso que simboliza o plano amarelo da sigla Paris ctônica: o clichê trazido do mundo subterrâneo pelo fotógrafo? Essa chapa, onde se impregnou a memória de infância da metrópole, o historiador está prestes a revelá-la. Ela também faz lembrar a idéia da escrita autêntica, no sentido mallarmeano: uma mensagem luminosa escrita pelas constelações nas trevas do tempo (53).

As outras três categorias - Recep̧̧ão, Recep̧̧ão em geral e Tradição, também incluídas em nossa constelação III - estavam previstas por Benjamin como introdução e conclusão do Modelo das passagens. Elas têm um elemento gráfico em comum com as siglas amarelas: o círculo que, aqui também, representa o recorte de um tempo ou objeto histórico em relação a outro.

10. Recepsãa, círculo vermelho. O recorte do objeto pelo historiador pode ser observado tanto num fragmento da categoria anterior - que fala do frontispíco das Águas-fortes de Paris, de Charles Méryon, onde aparece uma pedra com incrustações de moluscos, "escolhida entre amostras do solo primitivo de Paris" [L4a,4] - quanto nesta observação de Benjamin sobre a importância de Baudelaire no Projeto das passagens.

Minha intenção é mostrar como Baudelaire está incrustado no século dezenove. A marca que ele deixou, tem de ser realçada de modo tão nítido e tão intacto como a de uma pedra que, um dia, é retirada do lugar onde jazia durante décadas. [J51a,5].

Em ambos os casos, trata-se de ler a Urgeschichte da capital do século XIX a partir das marcas que ela deixou na obra dos artistas. Metodologicamente falando, a imagem do poeta como pedra incrustada no solo da metrópole representa a concepção de um estudo monadológico. Idéia cara a Benjamin e por ele resumida nas teses Sobre o conceito de história: é na obra determinada que é resguardada e preservada a obra de uma vida, na obra de uma vida, a época, e na época, a totalidade do percurso histórico (54). 
11. Recepção em geral, círculo cor-de-rosa. Esta categoria é, ao que tudo indica, uma versão anterior de 10. Recepção, que retoma um número considerável de seus fragmentos, com uma orientação mais teórica. A "recepção geral" da obra de Baudelaire - onde se destacam a comparação com Dante (v. 2l. Dante) Fisionomia do Inferno) e a perspectiva da arte pela arte (v. 30. Gautier/a arte pela arte) - é analisada como um pedaço da história geral. É a base a partir da qual Benjamin formula sua própria recepção do poeta, que é política, marcada pela experiência do fascismo. O círculo vermelho em 10. Recepção pode representar a telescopagem histórica de que fala o autor numa carta a Werner Kraft (GS V, p. 151): ele estava construindo "um telescópio", para poder "enxergar além das brumas de sangue" e decifrar "uma miragem do século XIX": os antecedentes do mito e da violência no século XX.

12. Tradição, seç̧ão de círculo cor-de-rosa. Com esta figura geométrica, que lembra o compasso na mão da Melancolia de Dürer, Benjamin secciona o tempo, recortando citações estratégicas. Trata-se de "arrancar a tradição ao conformismo que está prestes a dominá-la" (GS I, p. 695; $O E \mathrm{I}$, p. 224). O objetivo é um "resgate" e uma "salvação" (Rettung) da obra de Baudelaire (v. 27. Salvação) contra assimilações convencionais, como a "empatia", a "apologia", a "homenagem", em suma, sua utilização a serviço de uma ideologia.

\section{Planos de Paris}

Siglas: todos os retângulos e quadrados, sendo três já conbecidos (1. Melancolia 6. o Herói 9. Paris ctônica), dois aqui introduzidos (13. Antigüidade parisiense 14. Rebelde e alcagüete) e três apresentados mais adiante (15. a Mercadoria 16. o Flâneur e a Massa 19. Disposição sensitiva).

TESE-RESUMO: O sistema benjaminiano das siglas inscrepe-se na tradição da arte cartográfica e do gênero dos mapas de cidades (55). Ao mesmo tempo mimética e nãomimética, simples e complexa, essa forma de organização corresponde à necessidade de uma visão de conjunto e de uma orientação numa obra difícil, fragmentária e labirintica. É uma iniciação ao espaço simultâneo e polifônico da metrópole moderna. Os diferentes planos que se sobrepõem neste mapa de Paris representam o tecido urbano em seus diversos nípeis: redes subterráneas e ctônicas (metrô, catacumbas), o traçado das ruas e praças na superficie, com seus cruzamentos, sinais, anúncios luminosos, e, acima, contra fundo escuro, a escrita do universo. Se reunissemos todas as 30 siglas numa única página, não linearmente, mas segundo sua sintaxe espacial, obteriamos "a partir desses pontos luminosos, uma figura como uma constelação" (56).

Reunimos aqui o conjunto das siglas formadas por retângulos e quadrados, ao todo oito. Seu elemento geométrico comum, o plano retangular, representa desde os hieróglifos egípcios a morada: o espaço de uma casa, de um bairro, ou de uma cidade: 
E muitos quadrados vermelhos marcariam os aposentos

Do amor da mais baixa espécie ou do amor mais abrigado do vento.

O retângulo sugere também o que foi uma das principais invenções na história da escrita: o campo da página, suporte topológico para todo tipo de signos (57). As correspondências entre o uso topológico da página e o espaço urbano evidenciam a estruturação cartográfica do Modelo das passagens.

13. Antigüidade parisiense, quadrado vermelho. A legenda supra-citada do Pharusplan de Berlim, enquanto proto-texto das siglas, acentua a relação afetiva entre o escritor e a cidade. O vermelho é retomado com uma citação de Proust falando do "papel das cidades antigas em Baudelaire e da cor escarlate que introduzem em vários pontos de sua obra" [J43a,4]. As cidades destruídas da Antigüidade são para o escritor da metrópole moderna um memento mori, no sentido de incentivá-lo a produzir um texto que seja "digno de se tornar antigo", um texto duradouro. Quanto à forma da sigla, podemos nos lembrar da vista sobre a cidade medieval em Notre Dame de Paris, de Victor Hugo, onde o espaço urbano se estrutura ao longo de quatro eixos: dois no sentido Norte-Sul (Porta Saint-Martin - Porta Saint-Jacques, Porta Saint-Denis - Porta Saint-Michel) e dois no sentido Leste-Oeste (Porta Saint-Antoine - Porta Saint-Honoré, Porta Saint-Victor - Porta Saint-Germain) (58). Na cidade moderna, correspondemlhe representações literárias como o retângulo vazio simbolizando o "mapa de Paris" em Le Paysan de Paris (1926), de Louis Aragon (59); ou textos triviais como os "mapas do metrô", onde cada linha é identificada por uma cor diferente.

14. Rebelde e alcagüete, quadrado cheio roxo. O olhar sobre a paisagem social e política no período de 1830 até os anos de 1850 mostra a história social entre o mito da Revolução e a realidade do capital. A cor da sigla, entre o vermelho e o azul, traduz o perfil de uma camada intermediária, economicamente instável e politicamente indecisa, da qual provinham os profissionais da cultura e da mídia: a bohème. Ao seguir os caminhos de Baudelaire pelos bares e cabarets, numa atmosfera carregada de vinho, Benjamin capta imagens de conspiradores e agentes da polícia, literatos e trapeiros, prostitutas e jornalistas. Da montagem dos planos desse ensaio cinematográfico resulta um quadro da mentalidade vigente:

Protegida pela corrupção parlamentar, a classe dominante faz história fazendo seus negócios (GS V, p. 52; Soc., p.37).

Com esta frase, o crítico resume a modernidade.

A constelação IV, Planos de Paris (figura 6) nos fornece um mapa de orientação e uma iniciação ao ritmo da metrópole moderna: os planos cromáticos 
luminosos sugerem vitrines e passagens, a polifonia das atrações e das dispersões, lugares de memória e locais próprios para se perder. A cidade inteira numa única página - sinopse que corresponde ao ideal geométrico dos administradores e planejadores. Mas, subreptíciamente, no mesmo suporte topológico, impõem-se os grandes espaços obscuros recalcados - tudo aquilo que é eclipsado pelo brilho da propaganda e da publicidade (60). No grande palco da cidade moderna, a iluminação elétrica dispensa o céu, o que nos afasta das mais antigas práticas de leitura e de escrita:

não se escreve, luminosamente, em campo escuro, o alfabeto dos astros, apenas, assim se indica, esboçado ou interrompido; o homem segue preto no branco (61).

É preciso imaginar cada uma das nossas sete constelações, todas essas incursões pela cidade, "luminosamente, em campo escuro". Depois de termos seguido, como em uma iniciação, quatro rotas camufladas de siglas (constelações I a $I V)$, poderíamos, então, retirar as máscaras pretas e sair à luz do dia para ter uma visão de conjunto (figura 7). O quadro de Piet Mondrian, Broadway Boogie Woogie (1942), composto de quadrados e retângulos, azuis, vermelhos, amarelos, cinza, nos dá uma idéia exemplar da busca, por parte dos artistas construtivistas, de uma linguagem capaz de expressar o impacto das metrópoles do século XX sobre os sentidos de seus habitantes. A dança dos signos na tela de Mondrian traduz a a git ação colorida da grande cidade, coreografia que eclipsa e ao mesmo tempo imita as constelações celestes, num diálogo sempre retomado, desde os tempos arcaicos até a p o e s i a concreta dos dias atuais (62).

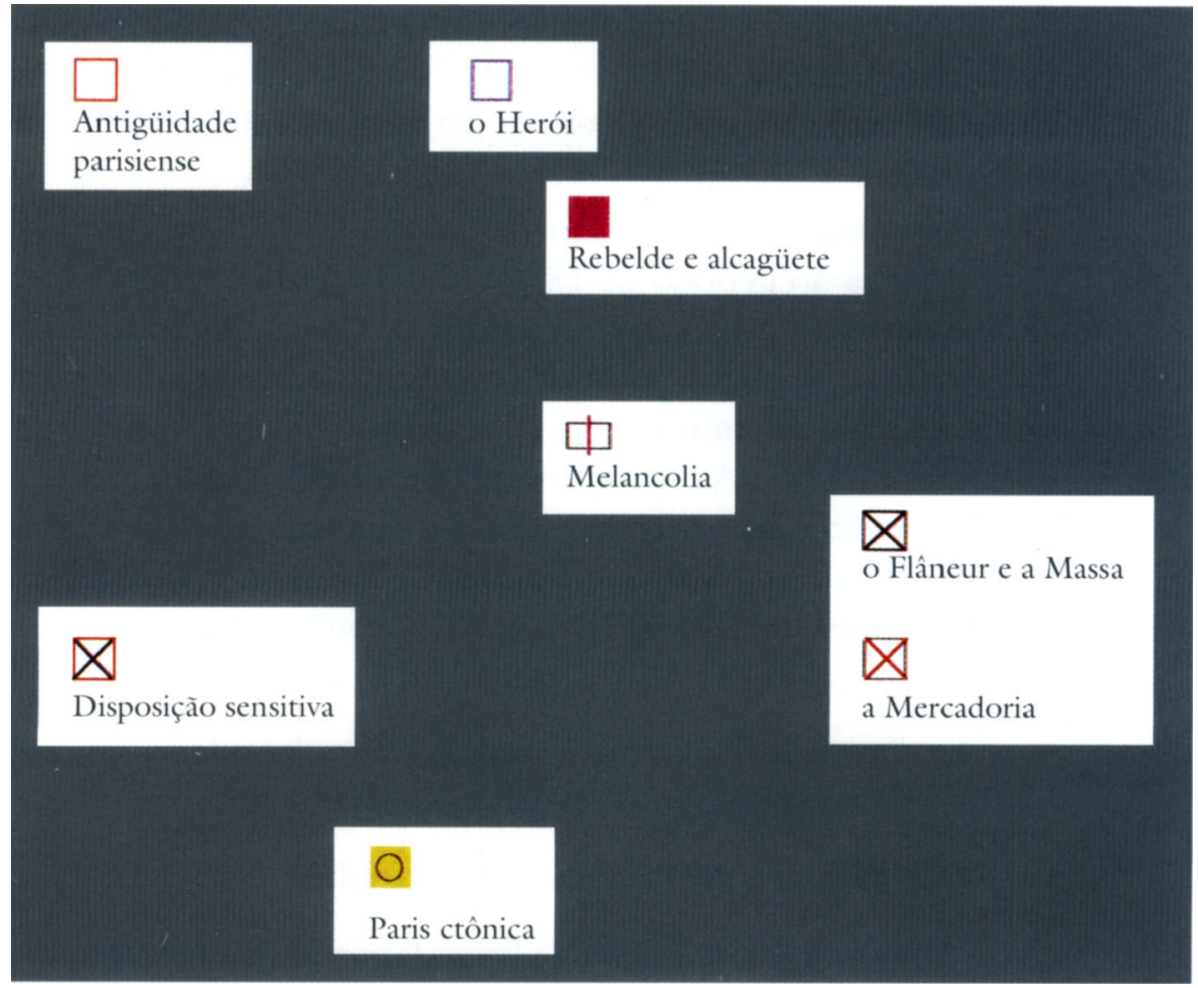

Fig. 6: Constelação IV: Planos de Paris 


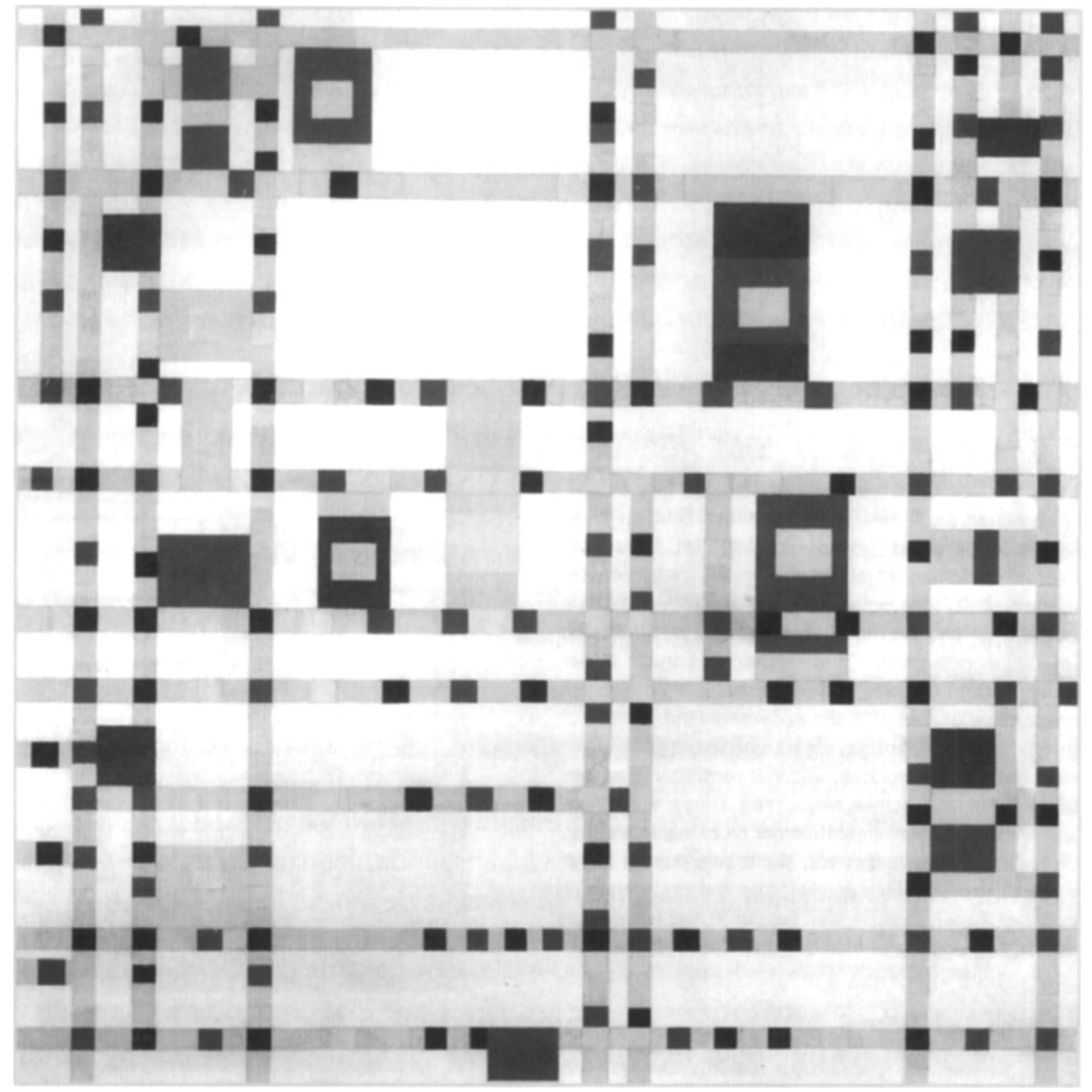

Fig. 7: Brodway Boogie Woogie (1942-1943), de Piet Mondrian. Museu de Arte Moderna, Nova Iorque. 


\section{Na encruzilhada da mercadoria}

Siglas: todos os cruzamentos, sendo dois já conbecidos (3. Spleen 5. o Dandy) e os cinco outros introduzidos aqui: 15. a Mercadoria 16. a Prostituta 17. o Flâneur e a Massa 18. Mercado literário 19. Disposição sensitiva.

TESE-RESUMO: Ao tomar a rota das siglas e ao reuni-las em sete constelações, seguimos a lógica gráfica e espacial inerente a esse sistema. No nosso mapa da cidade, a Mercadoria representa uma encruzilhada: é o centro da constelação das sete siglas cruzamento, simbolizando a circulação das mercadorias e as relações sociais na metrópole moderna. Enquanto emblema do capitalismo, a mercadoria age como um fetiche no imaginário social: peja-se o Flâneur e a Massa, a Prostituta, o Dandy e o Mercado literário. Lado a lado com quadros urbanos que acumulam fatos, há outros, mais reflexivos. Spleen $e$ Disposição sensitiva são casos especiais dentre as relações mercantís: a poesia é uma mercadoria que pensa (63). O conjunto das siglas em sua interação é como o corpo de baile de uma ciência poetizada.

Tendo chegado à quinta constelação, é o momento de explicitar um princípio metodológico que se impôs durante o percurso. $\mathrm{Na}$ análise das categorias não seguimos a ordem que elas teriam no texto, e sim, sua lógica constelacional - sem perder de vista a organização do livro-modelo em três partes. A seguinte análise das duas categorias-chave, 15. a Mercadoria e 20. Alegoria, permite-nos pôr em evidência sua função de grandes signos estruturadores do conjunto do Modelo das passagens. Em suas reflexões sobre a composição, Benjamin determinou estas prioridades:

Os temas mais importantes deverão ser definidos segundo sua localização na tese, na antítese e na síntese [partes I, II e III]... O centro das coordenadas na esquematização da parte I será formado pela Morte ou pelo cadáver. No lugar correspondente da parte III estará a Mercadoria, enquanto realidade social na qual se fundamenta o domínio do princípio de morte, nessa poesia (64).

Reconhecemos as duas categorias-siglas centrais que condensam como chips todo o circuito de categorias-siglas secundárias que elas comandam. Trata-se de uma "dispositio em grandes massas discursivas", como nas siglas de Joyce (65). Em suas reflexões sobre a composição, Benjamin cogitou sobre a distribuição das diferentes categorias nas três partes do livro e sobre sua concatenação (66). Essa questão, no entanto, torna-se relativa em função das diversas disposições constelacionais (67). Também deixaram sua marca na composição do Modelo das passagens "as cidades gigantescas", com o "cruzamento de suas inúmeras relações", de que nos fala Baudelaire no Spleen de Paris (OC, p. 229). Por tudo isso, invertemos aqui a ordem do livro, mostrando num primeiro momento o circuito das relações sociais regido pela :Mercadoria e a seguir a via do conhecimento crítico sob o signo da Alegoria. 
15. a Mercadoria, cruzamento vermelho num quadrado preto. Categoriachave da parte III do livro-modelo ("A mercadoria como objeto poético"), ela é o signo que rege as relações humanas no mundo capitalista. Como ela se manifesta? A referência de Benjamin ao grand magazin La Ville de Paris [A3a,3] pode ser lida de maneira alegórica: a metrópole moderna é "uma grande loja, onde o homem é a mercadoria que circula" (68). Nesta sigla podemos ver a representação de uma vitrine onde está exposto um objeto com atributos eróticos:

A embriaguez a que se entrega o flâneur é a da mercadoria rodeada e levada pela torrente dos fregueses ( $G S$ I, p. 558; OE III, p. 51 s.; Soc., p. 82).

Somam-se a isso as encenações publicitárias que tentam fazer da mercadoria um objeto de culto:

Exposições universais são os locais de peregrinação ao fetiche da Mercadoria (GS V, p. 50; Soc., p. 35).

A teoria marxista do fetichismo da mercadoria é reformulada por Benjamin como "empatia com a alma da mercadoria" (69). As categorias seguintes mostram como o emblema-mor do capitalismo atua no imaginário social e nas relações entre as pessoas.

16. a Prostituta, cruzamento roxo. É na obra de Benjamin que ela é elevada, pela primeira vez, a categoria histórico-filosófica. Enquanto "personificação da mercadoria", a prostituta é "a alegoria transformada em ser humano" (GS I, p. 151). Ela foi incluída por Baudelaire na confraria da bohème, dos literatos que vendem seus pensamentos íntimos. Quanto à forma da sigla, é curioso observar que no Caderno do poeta encontra-se uma lista de "bons endereços" (OC, p. 1306), onde certos nomes (Aline Lorin, Bathilde, Mad. Guichardet etc.) vêm acompanhados de um " $\mathrm{X}$ " - cujo significado o editor desconhece.

\17. o Flâneur e a Massa, cruzamento preto num retângulo preto.O flâneur é uma alegoria do literato que vai ao mercado, "pensando que é para olhar, mas, na verdade já é para encontrar um comprador" (GS I, p. 536; OE III, p. 30; Soc., p. 64). É também uma alegoria dos intelectuais da geração de Benjamin, fascinados pelo fenômeno das massas oprimidas, que estariam à sua disposição para resistir aos opressores e realizar a revolução. Através de um estudo da representação da multidão nos escritores do século XIX, Benjamin faz com que o objeto do fascínio se torne transparente: a massa é em primeiro lugar "um ajuntamento em massa de fregueses", que os estados totalitários sabem utilizar para seụs fins.

X 18. Mercado literário, cruzamento marrom. (A cor faz lembrar as tabuletas de argila da escrita cuneiforme, inventada por necessidades mercantís). Com o 
fim do mecenato, a geração de Baudelaire foi a primeira a fazer a experiência da literatura como mercadoria e do público como massa. O subtexto são as experiências de Benjamin como "escritor autônomo" na República de Weimar. Sobre o seu "encargo social", o poeta (assim como o intelectual) "não podia mais se informar junto a nenhuma classe"; ele tinha que deduzí-lo das conjunturas do mercado ( $G S$ I, p. 665; OE III, p. 158s.; Soc., p. 130). Foi com base nessa experiência que Baudelaire escolheu sua estratégia poética.

凶

19. Disposição sensitipa, cruzamento preto num quadrado vermelho. Esta categoria fala dos procedimentos de Baudelaire para registrar a sensibilidade moderna, que é "o verdadeiro assunto da poesia". Conhecedor dos artifícios da moda, da novidade e do reclame que constroem e disfarçam o mundo da aparência, Baudelaire assumiu a poesia como mercadoria, mas como mercadoria que reflete sobre a própria condição. Isso também se nota na confeç̧ão desta sigla, que é o avesso da sigla 15. a Mercadoria, cruzamento vermelho num quadrado preto. Da mesma forma que nas alegorias medievais, o interior é voltado para o exterior. (Como a Vênus do pantheon dos antigos, transformada em DamaMundo, bela e sensual de frente, mas atrás roída de vermes). Os atributos eróticos da mercadoria são substituídos pela exposição de uma cadáver, visto de dentro:

A alegoria barroca vê o cadáver só do lado de fora. Baudelaire o vê também de dentro (GS I, p. 684; OE III, p. 175; Soc., p. 146).

Apresentação que evidencia o caráter específico da alegoria no século XIX e o seu poder de se erigir em antagonista da mercadoria.

\section{Um hieróglifo crítico: a Alegoria}

Siglas: todas as cruzes, sendo três já conhecidas (4. Elementos fisionômicos 7. Jugendstil 8. Reação política) e as outras sete aqui introduzidas: 20. Alegoria 22. Lesbos 23. Paixão estética 24. Novidade 25. Perda da aura 26. Progresso 27. Salvação-e mais a sigla 21. Dante/Fisionomia do Inferno.

TESE-RESUMO: A segunda sigla-encruzilbada é a Alegoria, regendo um total de 10 siglas que têm como traço distintivo a cruz. Formam uma via crucis, centrada num tronco vertical de cor verde, de onde saem três braf̧os horizontais: cruzes simples (Lesbos, Reação política, Novidade), cruzes num circulo ou numa elipse (Salvação, Progresso, Perda da aura) e cruzes sobrepostas a círculos cheios (Jugendstil, Elementos fisionômicos, Paixão estética). A alegoria é a antítese da mercadoria: depois de ter sido, na Idade Média, um instrumento de desvalorizacãa da iconografia pagã, e, na época do Absolutismo, um signo de legitimaşão do poder, foi redescoberta por Baudelaire e Benjamin como um meio de desmascarar o fetichismo mercantil e de desconstruir os mitos da modernidade (Novidade, Progresso, Eterno Retorno). A alegoria, contudo, não é apenas destruidora, mas pode resgatar potenciais de sentido contidos nos mitos. 
- 20. Alegoria, cruz preta cortando um círculo verde cheio. Sob o signo da alegoria, Benjamin interpretou o drama barroco alemão, e é sob o mesmo signo que ele analisa a poesia da modernidade (cf. a parte I do livro-modelo, intitulada Baudelaire, poeta alegórico). Acompanhemos a via crucis formada por esta constelação de siglas a partir do tronco de cor verde. O verde, do latim viridis, "cheio de seiva", é a cor que representa a natureza. Como neste verso que evoca a deusa ctônica:

Cibele, que os adora, o verde faz crescer ( $O c$, p. 18, trad. Ivan Junqueira).

Mas sobre essa exaltação da natureza se projeta a alegoria como signo de mortificação, como "banimento do orgânico", a cruz preta cortando a

impudência da natureza vicejante [J27a,1].

Signo do sacrificio, da Paixão e da Ressurreição, a alegoria se transforma, na interpretação de Benjamin, no instrumento historiográfico por excelência, na medida em que permite desmascarar o mito e a aparência.

21. Dante / Fisionomia do Inferno, linha serpentiforme (70) verde. Segundo o crítico André Suarès, "As Flores do Mal são o Inferno do século XIX" $(\mathrm{J} 11,4)$. À imagem das serpentes no inferno de Dante correspondem, em Baudelaire, a linha ondulada da sensualidade, a atração pelas plantas carnudas e por tudo que há de voluptuoso e violento na physis exuberante - que se torna sinônimo de pecado.

$+\quad 22$. Lesbos, cruz verde. Recortado sobre o círculo verde cheio da sigla 20. Alegoria, é mais um dos emblemas do "banimento do orgânico". À imagem da lésbica, que aparece em Baudelaire como heroína da modernidade, Benjamin acrescenta como legenda uma palavra de ordem da feminista Claire Demar: "Chega de maternidade!" [p2a,1]. Segundo o poeta, "as crianças são as criaturas mais próximas do pecado original" [J63a,1].

23. Paixão estética, cruz preta sobreposta a um pequeno círculo roxo cheio. A cor faz lembrar uma caracterização de Baudelaire por Champfleury como “jibóia roxa" [J14a,2]. Uma vez que Benjamin não apresenta provas convincentes quanto à suposta "impotência" de Baudelaire e não distingue claramente entre "impotência", "infertilidade" e "renúncia em formar uma família", seu conceito de paixão estética, calcado na idéia da "via-sacra da sexualidade masculina", permanece bastante vago. Isso afeta também sua tese da impotência da classe burguesa, que teria "deixado de se ocupar com o futuro das forças de produção que ela engendrou" (GS I, p. 664; OE III, p. 157; Soc., p. 129). 
+ 24. Novidade, cruz cor-de-rosa. A ambigüidade da sigla - que pertence simultaneamente ao circuito da Mercadoria (pela cor) e ao da Alegoria (pela forma) - traduz a utilização dialética dessa categoria por Baudelaire. O poeta definiu a modernidade com base na moda e no mito da novidade. (O novo é "a auréola da mercadoria", dirá Benjamin). Percebeu como uma das leis da modernidade o fato de ela envelhecer rapidamente. Às exigências de um mercado dominado pelos imperativos da moda, Baudelaire respondeu, heróica e sarcasticamente, com um tipo de poesia em que o novo é a viagem até a morte:

Ó Morte, velho capitão, é tempo! Às velas!

[...]

Queremos, tal o cérebro nos arde em fogo, Ir ao fundo do abismo, Inferno ou Céu, que importa?

Para encontrar no Ignoto o que ele tem de novo!

(OC, p. 127, trad. Ivan Junqueira).

25. Perda da aura, cruz preta numa elipse marrom. Esta figura geométrica sugere a órbita de um astro extinto. A poesia de Baudelaire brilhando no firmamento do Segundo Império como "um astro sem atmosfera" - eis a imagem final do ensaio escrito por Benjamin em 1939 (GS I, p. 653; OE III, p. 145). A sigla pode também figurar a órbita ocular, uma vez que a perda da aura concerne também ao olhar das pessoas, onde se nota uma perda da capacidade de responder ao olhar do outro ( $G S$ I, p. 649; OE III, p. 142). A importância do diagnóstico de Baudelaire quanto à perda da aura só ficou reconhecida plenamente através da retomada dessa categoria por Benjamin, na análise das técnicas de reprodução e do poder da mídia nos anos 1930. Diante das contradições entre o potencial emancipatório dos novos meios e sua utilização cultual pela arte fascista das massas, o crítico procurou resgatar a aura:

Talvez seja necessário experimentar o conceito de uma aura depurada de seus fermentos cultuais? Talvez o declínio da aura seja só uma fase transitória, em que ela elimina seus fermentos cultuais, para enriquecer-se com outros, ainda não identificáveis? ( $G S$ VII, p. 752s.)

26. Progresso, cruz preta num círculo azul. Estamos diante do mito central da modernidade; significativamente, esta categoria se encontra no mesmo maço ("N") do acervo de materiais que a teoria do conhecimento. Sob o impacto de uma modernidade que era para ele e a sua geração a época marcada por duas guerras mundiais, Benjamin combateu esse mito durante sua vida inteira. Face à Primeira Guerra Mundial, escreveu:

Há uma concepção da história que, confiando na eternidade do tempo, só distingue o ritmo dos homens e das épocas que rodam rapida ou lentamente pela estrada do progresso (GS II, p. 75; $D C D B$, p. 151). 
A imagem do rodar pela estrada pode ter dado origem à forma circular da sigla; a cor azul celeste, conotando o infinito, se encontra tanto aqui quanto na sigla 28. Eterno Retorno. Face à Segunda Guerra Mundial, Benjamin criticou a concepção do progresso enquanto "norma histórica", a "obtusa fé no progresso" por parte dos "políticos, nos quais os adversários do fascismo tinha depositado suas esperanças". Essa mentalidade, que remonta ao positivismo e ao marxismo doutrinário do século XIX, "enxerga apenas o progresso na dominação da natureza, e não o retrocesso na organização da sociedadẹ. Já estão visíveis, nessa concepção, os traços tecnocráticos que mais tarde vão aflorar no fascismo" ( GS I, p. 698s.; $O E \mathrm{III}$, p. 227s.).

27. Salvação, cruz preta num círculo verde. "A concepção verdadeira do tempo histórico", escreve Benjamin, "está inteiramente baseada na imagem da redenção" [N13a,1]. Esse conceito, tomado da tradição messiânica, corresponde ao de salvaf̧ão na teoria platônica. Ambos têm um compromisso com as expectativas não cumpridas do passado. Juntamente com o "resgate" das obras (cf. 12. Tradição), o crítico visava "libertar o futuro de sua forma presente desfigurada, através de um ato de conhecimento" ( $G S$ I, p. $7.5 ; D C D B$, p. 151). A sigla na qual o verde substitui o azul da sigla anterior e a cruz da morte se transforma na de salvação, anuncia essa mudança. Como alternativa aos supostos "progressos de dominação da natureza" por uma tecnocracia toda-poderosa, Benjamin propôs o resgate das utopias:

A imagem da verdadeira natureza, trabalhada pelo homem libertado, é algo que ainda é preciso desenvolver (GS VII, p. 744s.).

\section{A radiografia do surrealismo}

\section{Siglas: a triade dos triángulos: 28. Eterno Retorno}

\section{Banimento do organico 30. Gautier/a arte pela arte}

TESE-RESUMO: Desde seu contato com o surrealismo, a partir do qual nasceu o Projeto das passagens, Benjamin imaginava uma história da "poesia esotérica", cujo "ressurgimento" poderia explicar a crise das artes de que ele foi testemunha. Escrita como obra de um indivíduo, por necessidade interior, apresentaria na última página "a radiografia do surrealismo" (71). Pode-se dizer que Benjamin, com o Modelo das passagens, forneceu tal radiografia. É o único de seus escritos a por em obra a totalidade das categorias históricase filosóficas que compõem a fisionomia da modernidade - por meio de uma escrita esotérica, que permite apresentar o todo em forma de uma constelação, numa única página, com uma qualidade de olbar que torna transparente a mitologia do século XX.

As três categorias que ainda faltam (figuradas nas siglas por triângulos) contribuem para corroborar esta tese. 
28. Eterno Retorno, triângulo azul. Um dos principais resultados da pesquisa de Benjamin sobre a mitologia da modernidade foi a descoberta da dialética entre o novo e o sempre-igual - relação representada pela dupla das categorias 24. Novidade e 28. Eterno Retorno. Em Baudelaire, a novidade é conquistada a partir do sempre-igual; em Nietzsche, o homem encara o sempre-igual heroicamente; em Blanqui, a experiência do sempre-igual leva à resignação (cf. GS I, p. 673; OE II, p. 165; Soc., p. 173). Seu livro A eternidade através dos astros (1872) expressa uma concepção segundo a qual, nas épocas pós-revolucionárias, só existe o tempo eterno e imutável dos vencedores. Contra essa visão, "onde convergem as fantasmagorias do século XIX", Benjamin põe um conceito de história, em que "o passado é sempre redefinido pelo agora" (resumo do fragmento N9a,3). A concepção do eterno retorno é posta em xeque pelas duas outras categorias-triângulo:

29. Banimento do orgdnico, triângulo invertido marrom. O marrom enquanto cor da morte ("Triângulos marrons, os túmulos") é projetado sobre o triângulo púbico - signo muito antigo, já encontrado na escrita suméria (72). É “o órgão do nascimento", como Benjamin o denomina no seu livro sobre o drama barroco. O homem nasce sob esse signo, mas este se metamorfoseia em memento mori, lembrando ao homem que não dispõe da eternidade. Essa consciência está representada na Melancolia de Dürer (fig. 3) na figura da pedra: no triângulo invertido aparece uma caveira. Contudo, essa gravura contém um movimento de reversibilidade: ao lado, há outro triângulo que aponta para cima. Dialética evidenciada por Benjamin pela sigla

30. Gautier/l'art pour l'art, triângulo cor-de-rosa cheio. Ao desafio da morte, $\mathrm{o}$ homem pode responder através da arte. $\mathrm{O}$ triângulo representaria na gravura de Dürer a ponta ampliada de um buril, no quadro de Baudelaire (fig. 4), o instrumento da escrita. Desde as mais antigas iconografias, o triângulo que aponta para cima é o emblema da virilidade, marcado aqui com a cor da aurora. A propósito, citemos um trecho do ensaio O pintor da vida moderna:

$O$ gênio não é senão a infầncia reencontrada por um ato de vontade, $a$ infância dotada agora, para expressar-se, de órgãos viris e espírito analítico (OC, p. 1159).

Baudelaire, ao dedicar as Flores do mal ao mago das letras Théophile Gautier, acentuou a primazia da forma e da durabilidade - uma estratégia que, ainda décadas depois, é reconhecida pela crítica: "Não há nada, nessa poesia, que tenha envelhecido" [J60a,1].

Como vimos neste percurso pela paisagem das siglas de Benjamin, sua historiografia se realiza, em forte medida, através de categorias estéticas. Foi com os artistas que aprendeu o ofício. Com Baudelaire, o "pintor da vida moderna", 
tem em comum a capacidade de reproduzir imagens mnemônicas com o frescor de "impressões matinais". Há um texto da Infância berlinense por volta de 1900, em que a criança, numa de suas ocupações prediletas, a decalcomania, "cautelosamente gira, esfrega e raspa" a capa que recobre as imagens, até que, por fim, as cores despontam, "como se irrompesse sobre a turva manhã o sol radiante de setembro" (73). Aqui se antecipam os procedimentos do historiador: despertar, revelar, aprender a ver. Na gravura de Dürer, fascinava-o o olhar super-desperto e divinatório da Melancolia. Trata-se da percepção de um artista que teve diante dos olhos a "facies hippocratica da História" - sua própria história e a de sua época - "como uma paisagem arcaica petrificada" (GS I, p. 343; Origem, p. 188), e que soube decifrá-la. Com esse olhar, Benjamin transmitiu aos pósteros “o mais sonhado de seus objetos, a cidade de Paris" - com suas "encruzilhadas ou cruzamentos onde brilham, de repente, no meio do trânsito, sinais espectrais; onde podem ocorrer a qualquer momento analogias inauditas e coincidências de acontecimentos" (GS II, p. 301; DCDB, p. 110). Trata-se de uma qualidade de olhar que possibilita uma escrita radiográfica da História (74). Idéia cuja formulação lacônica já se encontra em Dürer: "Perspectiva é uma palavra latina que significa olhar através" (75).

\section{Notas}

1 Walter Benjamin, Gesammelte Schriften (edição citada daqui em diante como GS), Frankfurt a.M., Suhrkamp, 1972-1989, v. IV, p. 112; Obras Escolhidas, v. II, São Paulo, Brasiliense, 1987, p. 36. A edição das Obras Escolbidas (v. I, 1985; v. III, 1989; vários tradutores)será citada como $O E$. Há interpolações minhas nas traduções publicadas.

2 Das Passagen-Werk, GS V, edição estabelecida por Rolf Tiedemann, 1982; Parigi, capitale del XIX secolo. I "Passages" di Parigi, ed. organizada por Giorgio Agamben, trad. Renato Solmi et al., Turim, Einaudi, 1986; Paris, capitale du XIXe siècle. Le Livre des Passages, trad. Jean Lacoste, Paris, Cerf, 1989. O título alemão, assim como o estatuto de obra (Werk), atribuídos pelo editor a esses escritos, têm sido contestado. $\mathrm{Na}$ verdade, Benjamin nunca usou tal designação - falou inicialmente de Passagens parisienses, depois de Paris, capital do século XIX (título de dois exposés) e, na maioria das vezes, de Trabalho das passagens.

3 Louis Hay, "L'écrit et l'ir.uprimé", em De la lettre au livre. Sémiotique des manuscrits littéraires, org. por Louis Hay, Paris, Éditions du CNRS, 1989, p. 7-34; aqui, p. 25.

4 Ver Naissance de l'écriture. Cunéiformes et hiéroglyphes, catálogo de exposição, Paris, Éd. de la Réunion des Musées Nationaux, 1982.

5 Para mais detalhes, ver Louis Hay (nota 3), de quem foram tomados esses exemplos.

6 L. Hay (nota 3), p. 11. 
7 Ver os documentos sobre a gênese do Trabalho das passagens em GSV, p. 1081-1205; GS I (que contêm os textos sobre Baudelaire) p. 1064-1136; e GS VII (Nachträge), p. 852-872.

8 Usamos portanto Trabalho das passagens como referência ao projeto inteiro (19271940), e Modelo das passagens como sinônimo do livro inacabado Baudelaire, um poeta no auge do capitalismo (1938), cujo plano de construção existe na íntegra.

9 G. Agamben, “Un importante ritrovamento di manoscritti di Walter Benjamin”, em Aut...Aut... (Florença), 1982, no 189/190, p. 4-6. Em 1995, a Bibliothèque Nationale foi intimada pela fundação que detém os direitos de propriedade sobre os textos de Benjamin de entregar os manuscritos para o Theodor W. Adorno Archiv.

10 Sobre as relações entre a gênese e a recepção do Trabalho das passagens, ver W. Bolle, Fisiognomia da Metrópole Moderna. Representação da História em Walter Benjamin, São Paulo, Edusp, 1994, p. 42-51. Sobre o Modelo das passagens, no contexto da teoria benjaminiana da História, ver, em próximo lançamento, W. Bolle, "Geschichte", em Benjamins Begriffe, edição organizada por Michael Opitz e Erdmut Wizisla, Frankfurt a.M., Suhrkamp, 1997.

11 Ver nota 2.

$12 G S \mathrm{~V}, \mathrm{p}$. 1263. O conjunto dos manuscritos de materiais e notas se compõe de 426 fólios duplos de $14 \times 22 \mathrm{~cm}$.

13 Como não foi possível fotografar os manuscritos de Benjamin, eles são apresentados em forma de esquematizações didáticas (figuras la e lb). Como se vê, trata-se de um texto metade em alemão, metade em francês, estando o primeiro em escrita gótica e o todo em letras minúsculas. Os fragmentos do acervo de materiais e notas ( GS V, p. 79-989) são citados aqui assim como aparecem no plano de construção, ou seja, por sua referência alfanumérica.

14 O termo é tomado de Baudelaire (Le Spleen de Paris), que fala dos "cruzamentos" das inúmeras relações existentes nas cidades enormes, em Euvres complètes (citada daqui em diante como $O C$ ), ed. organizada por Y.-G. Le Dantec e Claude Pichois, Paris, 1961, p. 229.

15 "Pelo visto, a palavra transferido remete à confecção de um manuscrito novo [...]", Tiedemann em GS V, p. 1263.

16 Parigi, capitale del XIX secolo (nota 2), p. XIX.

17 Duas siglas - Natureza e Cidade e Romances policiais, acompanhadas da menção "cancelado no manuscrito" - não aparecem nos manuscritos da Bibliothèque Nationale, onde, em contrapartida, se encontram duas siglas que não constam da lista de Agamben: Recep̧̧ão em geral e Tradição; o autor manteve, portanto, o total de 30. Em comparação com a folha reproduzida por Agamben, o plano de construção da B.N. assim como o acervo de materiais de Frankfurt apresentam algumas divergências de formas e cores: a sigla para Eterno retorno, por exemplo, é um triângulo azul e não roxo. 
18 Uma só categoria pode ocupar mais de uma página.

19 Eis o que foi publicado até agora do plano de construção do Modelo das passagens: 1. Das reflexões gerais sobre a composição: o texto integral, em fac-simile e transcrição, GS VII, p. 744-764; 2. Dos esboços de capítulos: três dos 16 fólios, ou seja, $18.7 \%$, p. $740-742$; 3 . Das 30 categorias com 1.745 resumos de fragmentos: uma amostra de três categorias, com 30 resumos, ou seja, 1,7\%, p. 737s. Em suma, de um total de 86 fólios, foram publicados cerca de 16, isto é, aproximadamente $20 \%$.

20 GS V, p. 1264, e GS VII, p. 739.

21 Michel Espagne e Michael Werner, "Les manuscrits parisiens de Walter Benjamin et le Passagen-Werk", em Walter Benjamin et Paris. Colloque international 27-29 juin 1983, org. por Heinz Wismann, Paris, Cerf, 1986, p. 849-882; "Vom Passagen-Projekt zum 'Baudelaire'. Neue Handschriften zum Spätwerk Walter Benjamins”, em Deutsche Vierteljahrsschrift für Literaturwissenschaft und Geistesgeschichte 58 (1984), p. 593657; “Bauplan und bewegliche Struktur im 'Baudelaire'. Zu einigen Kategorien von Benjamins 'Passagen-Modell', em Recherches Germaniques 17 (1987), p. 93-120; "Ce que taisent les manuscrits: les fiches de Walter Benjamin et le mythe des 'Passages", em Penser, classer, écrive. De Pascal à Pérec, org. por Béatrice Didier e Jacques Neefs, Presses Universitaires de Vincennes, 1990, p.105-118.

22 Espagne/Werner 1990 (nota 21), p. 109.

23 Espagne/Werner 1990, p. 110.

24 Kandinsky, Punkt und Linie zu Fläche, Berna, Benteli, $7^{\mathrm{a}}$ ed., 1973.

25 Este quadro foi estabelecido com base na observação comparada dos manuscritos originais na Bibliothèque Nationale de France e no Theodor W. Adorno Archiv. Com relação à descrição de Tiedemann ( GS V, p. 1264 e GS VII, p. 739), que examinou os mesmos materiais, cabe assinalar as seguintes divergências: 1 . Spleen - a cor do cruzamento não é amarela, e sim, laranja; 2. Novidade - a cor da cruz não é vermelha, mas rosa; 3. Gautier/a arte pela arte - a cor do triângulo cheio é vermelha nos primeiros maços revistos por Benjamin, depois há oscilação entre o vermelho e o cor-de-rosa, e, finalmente, opção pelo cor-de-rosa; 4. Tradição - trata-se de fato de uma secção de círculo, um quarto de círculo (identificação correta em GS V, mas incorreta em GS VII); sua cor, porém, não é vermelha, e sim, rosa; 5. Alegoria - oval ou círculo? Há oscilação entre as duas formas. Todavia, como a forma oval está muito discreta, não chegando à forma claramente marcada da elipse - como em Perda da aura-, reproduzo esta sigla em forma de círculo. Para a sigla "triângulo marrom invertido", encontra-se em Agamben e Espagne/ Werner a legenda Anschauung des Organischen (Contemplação do mundo orgânico), em Tiedemann Verfehmung des Organischen (Banimento do orgânico); esta última leitura é a correta. Quanto ao número das siglas, Tiedemann havia contado 32 no acervo de materiais (GS V), às quais acrescentou mais uma ( $R \varepsilon$ cepcão em geral) em GS VII - portanto, um total de 33. Mas, como as três siglas designadas em GS V por "m" (retângulo azul com cruz preta), "c l" (cruz amarela entre colchetes pretos) e "d l" (retângulo preto) não se encontram no plano de construção, fica-se no número de 30 . 
26 Quanto à utilização de sistemas de cores nas Artes e Ciências, ver Idee Farbe. Farbsysteme in Kunst und Wissenschaft, catálogo de exposição org. por Narciso Silvestrini e Urs Baumann, Zurique, Baumann \& Stromer, 1994. Agradeço pela indicação a Eberhard Lämmert.

27 GS V, p. $578[\mathrm{~N} 3,3]$.

28 François Furet, L'Atelier de l'Histoire, Paris, Flammarion, 1982.

29 Paul Klee, Das bildnerische Denken, Basiléia-Stuttgart, Schwabe \& Co., 1970, p. 471s.

30 GS I, p. 203-430, aqui: p. 329-335; Origem do drama barroco alemão (daqui em diante: Origem), trad. Sérgio Paulo Rouanet, São Paulo, Brasiliense, 1984, p. 174-180.

31 Claude Pichois e Jean Ziegler, Baudelaire, Paris, Julliard, 1987.

32 Ch. Baudelaire, oc (nota 14), p. 1158.

33 É nesses termos que Paul Desjardin caracteriza a poesia de Baudelaire, em GS I, p. 621; OE III, p. 115s.

34 Bertolt Brecht, Arbeitsjournal 1938 bis 1942, Frankfurt a.M., Suhrkamp, 1974, p. 14.

35 Carta de Horkheimer a Benjamin, 13-4-1937, em GS I, p. 1067.

36 Em carta a Horkheimer, de 28-3-1938, Benjamin explica que seu livro sobre Baudelaire seria um "modelo em miniatura" das Passagens, GS V, p.1164; em carta a Gershom Scholem, de 8-7-1938, diz que se trata de "um modelo muito exato das Passagens", GS I, p. 1079.

$37 \mathrm{Em}$ 1935, Benjamin encaminhou ao Institut für Sozialforschung, em Nova Iorque, o seu projeto de pesquisa, intitulado "Paris, capital do século XIX", GS V, p. 45-59; Sociologia (daqui em diante: Soc.), org. e trad. Flávio Kothe, São Paulo, Ática, 1985, p. 30-43.

38 “Zentralpark", GS I, p. 655-690; Soc., p. 123-152; OE III, p. 151-181.

39 Espagne/Werner 1990 (nota 21), p. 107. Geneticamente falando, houve duas fases de trabalho no plano de construção, de 1938: na primeira, Benjamin trabalhou com todas as 30 categorias no mesmo nível; na segunda, dissolveu 13 dessas categorias, não para eliminá-las, mas para repartí-las e integrá-las nas 17 que eram mantidas. Para o nosso trabalho, porém, não há nenhum empecilho de considerarmos o plano de construção com todas as $\mathbf{3 0}$ siglas numa perspectiva sincrônica.

40 GS II, p. 204-210 et 210-213; trad. da primeira versão em $O E$ I, 108-113.

41 Winfried Menninghaus, Walter Benjamins Theorie der Sprachmagie, Frankfurt a.M., Suhrkamp, 1980, p. 64s.

42 Viviane Koenig, La naissance de l'écriture, Paris, Hachette, 1990, p. 5.

43 Jean-François Champollion, Principes généraux de l'écriture sacrée égyptienne, Paris, Institut d'Orient-Michel Sidhom, 1984, p. XVIII. 
44 W. Benjamin, Berliner Chronik, ed. revista, Frankfurt a.M., 1988, p. 11. Ver o comentário em W. Bolle 1994 (nota 10), p. 332-336.

45 Franz Marc, apud John Gage, Colour and culture, Londres, Thames \& Hudson, 1994, p. 207. 46 Cf. GS I, p. 599s.; OE III, p. 93s.

47 Cf. "Sobre o conceito da história", GS I, p. 691-704; OE I, p. 222-232.

48 Franz Marc apud J. Gage (nota 45), loc. cit.

49 "Stefan George em Retrospectiva", GS III, p. 399; em Documentos de cultura-documentos de barbárie (daqui em diante: $D C D B$ ), org. por W. Bolle, trad. Celeste Ribeiro de Sousa et al., São Paulo, Cultrix-Edusp, 1986, p. 148.

50 Johann Wolfgang Goethe, Zur Farbenlebre, org. por Manfred Wenzel, Frankfurt a.M., Deutscher Klassiker Verlag, 1991, p. 250.

51 Ver Leon Battista Alberti, De Pictura, 1435, apud Gage (nota 45), p. 118.

52 Ao aproximar a "mitologia" da Urgeschichte ("história primeva"), Benjamin visa extrair dela o seu potencial histórico.

53 Ver nota 61 .

54 GS I, p. 703; OE I, p. 231; Soc. (nota 37), p. 163.

55 Sobre a importância da cartografia no imaginário dos artistas contemporâneos, ver Mapping, catálogo de exposição, New York, Museum of Modern Art, org. por R. Slor, 1994.

56 Cf. Carta de Benjamin a Gretel Adorno, 16.08.1935, Briefe, 2 vols., Frankfurt a.M., Suhrkamp, 1978, p. 688.

57 Cf. Louis Hay (nota 3), p. 18-22.

58 Victor Hugo, Notre Dame de Paris, em Ceupres completes, Roman I, Paris, Robert Laffont, 1985, p. 578s.

59 Louis Aragon, Le Paysan de Paris, Paris, Gallimard, 1933, p. 203.

60 Para uma leitura alegórica dos tempos sombrios no Brasil do século XX, ver Antonio Candido, A educação pela noite, São Paulo, Ática, 1987.

61 Stéphane Mallarmé, “L'action restreinte”, em Guvres complètes, ed. org. por Henri Mondor e G. Jean-Aubry, Paris, Gallimard, 1984, p. 370. Ver o comentário de Friedrich A. Kittler, Aufschreibesysteme 1800-1900, Munique, Fink, 3.a ed. 1995, p. 24ls.

62 Agradeço a Augusto de Campos a referência ao Broadway Boogie Woogie de Mondrian, no contexto de uma longa conversa, na fase preparatória deste estudo, sobre o uso de siglas na poesia contemporânea. A reprodução do quadro, bem como de toda uma série que o precedeu, está em Piet Mondrian, catálogo de exposição, Gemeentemuseum, Haia, org. por Yve-Alain Bois et al., Berna, Benteli, 1995. 
63 “A mercadoria procura ver seu próprio rosto", GS I, p. 671; OE III, p. 163; Soc., p. 135. 64 GS VII, p. 764.

65 Daniel Ferrer, "Les carnets de Joyce: avant-textes limites d'une œuvre-limite”, em Genesis 3, 1993, p. 45-61, aqui: p. 53. Para mais detalhes, ver Roland Mc Hugh, The Sigla of "Finnegans Wake", Londres, Edward Arnold, 1976.

66 Ver, a título de exemplo, a página 762 de GS VII, que começa com a palavra Reihenfolge (recte por Bucherfolge) e que trata da "seqüência" ou "ordem" das categorias.

67 As principais disposições constelacionais são: 1. A ordem muito solta dos fólios, à maneira de um baralho (de cartas do Tarô?); 2. A atribuição de um mesmo fragmento a mais de uma categoria (Mehrfachindizierungen), assunto minuciosamente estudado por Espagne e Werner; 3. O sistema das siglas, que podem ser consideradas como extensões icônicas para contatos múltiplos - como aquele dispositivo elétrico chamado benjamim.

68 Cf. GS I, p. 336; Origem (nota 30), p. 181.

69 Carta de Benjamin a Adorno, de 9-12-1938, Briefe II (nota 56), p. 792. Sobre o conceito original do fetichismo da mercadoria, ver Karl Marx, Das Kapital, MarxEngels Werke, v. 23, Berlim, Dietz Verlag, 1962, p. 86.

70 O termo "linha serpentiforme" (Schlangenlinie) é tomado de Albrecht Dürer, Instruction sur la manière de mesurer, trad. francesa, Paris, Flammarion, 1995, p. 28 - tratado publicado em 1525 e antecipando sob muitos aspectos o estudo de Kandinsky, citado na nota 24.

71 “Der Sürrealismus”, GS II, p. 301s.; DCDB, p. 110.

72 Cf. A. Falkenstein, Archaische Texte aus Uruk, Berlim-Leipzig, DFG-O. Harrassowitz, p. 25.

73 “Das Pult" (A escrivaninha), GS IV, p. 280-282; OE II, p. 118-120.

74 Em sua radiografia dos anos de 1920 e 1930 , Benjamin considerou não só o ressurgimento do esoterismo nas vanguardas, mas também a "contribuição importante" do esoterismo ao fascismo alemão, cujo principal emblema, a suástica, retomou a antiga roda de fogo ariana; cf. GS II, p. 228s.

75 Albrecht Dürer, Instruction sur la manière de mesurer (nota 70), p. 18.

\section{Resumo}

Do que era para ser seu opus magnum, o Trabalho das passagens, concebido como uma história social da cidade de Paris no século XIX, W. Benjamin elaborou em 1938 um modelo, que ficou inacabado, mas do qual existe um plano de construção integral, reencontrado em 1981 na Bibliothèque Nationale da França. Com base no deciframento desses manuscritos, $80 \%$ inéditos, é apresentada aqui uma síntese do Modelo das passagens, em forma de uma constelação das 30 siglas/em corç que simbolizam as 30 categorias construtivas. $O$ trabalho se baseia na hipótese de que se trata de uma escrita esotérica com valores estéticos, semânticos e estruturadores próprios: recurso mimético destinado a ler o texto difícil da 
metrópole moderna. As siglas são analisadas sob sete aspectos: oficina de historiografia, escrita fisiognômica, visualização do tempo, história como cartografia, quadros de mentalidade, alegorização e radiografia de época. Atuando na intersecção entre tradições conceituais e pictográficas, as siglas constituem na historiografia um gênero de fronteira.

\section{Abstract}

In 1938, W. Benjamin elaborated a model of his major work, the Arcades Project, conceived as a social history of the city of Paris in the 19 th century; the model remained unconcluded, but there is an integral plan of its construction, discovered in 1981 at the Bibliothèque Nationale of France. Based upon the deciphering of these manuscripts, $80 \%$ unpublished, this article presents a synthesis of the Arcades Model, in form of a constellation of the 30 colored sigla which symbolize the 30 constructive categories. The working hypothesis is that they are an esoteric script, with specific aesthetic, semantic and structurizing values: a mimetic instrument appropriated to read the enigmatic text of the modern metropolis. Seven aspects of the sigla are presented in this analysis: historiographical workshop, physiognomical scripts, visualization of time, history as cartography, pictures of mentality, allegorization, and history as radiography. As they operate on the boundary of conceptual and pictographical traditions, the sigla constitute a frontier genre in historiography.

\section{Résumé}

En 1938, W. Benjamin a elaboré un modèle de ce qui devait être son œuvre majeure, le Livre des Passages, conçu comme une histoire sociale de la ville de Paris au XIXe siècle modèle inachevé, mais il en existe un plan de construction intégral, retrouvé en 1981 à la Bibliothèque Nationale de France. Basé sur le déchiffrement de ces manuscrits, dont $80 \%$ sont inédits, nous présentons une synthèse du Modèle des Passages, sous forme d'une constellation des 30 sigles en couleurs qui symbolisent les 30 catégories constructives. Nous travaillons sur l'hypothèse qu'il s'agit d'une écriture ésotérique, avec des valeurs esthétiques, sémantiques et structurantes propres: instrument mimétique destiné à lire le texte difficile de la métropole moderne. Les sigles sont analysés sous sept aspects: chantiers d'historiographie, écriture physiognomonique, visualisation du temps, l'histoire comme cartographie, tableaux de mentalités, allégorisation et histoire radiographique. Opérant à l'intersection des traditions conceptuelles et pictographiques, les sigles constituent dans l'écriture de l'histoire un genre de frontière.

Willi Bolle é professor do Departamento de Letras Modernas da Faculdade de Filosofia, Letras e Ciências Humanas da USP.

Este estudo foi apresentado em 19 de fevereiro de $1996 \mathrm{em}$ forma de conferência na École Normale Supérieure. O autor o dedica a Louis Hay, que o estimulou a realizá-lo. Agradece à Bibliothèque Nationale de France e ao Theodor W. Adorno Archiv em Frankfurt pelo acesso aos manuscritos originais, a Michel Espagne, assim como à equipe do Institut des Textes et Manuscrits Modernes, pelo diálogo, e ao CNPq pela bolsa que possibilitou a execução desta pesquisa. Revisão do original em francês: Philippe Willemart.

Tradução de Jean Briant e Monique Aron Chiarella. 